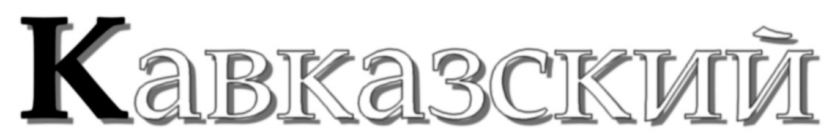

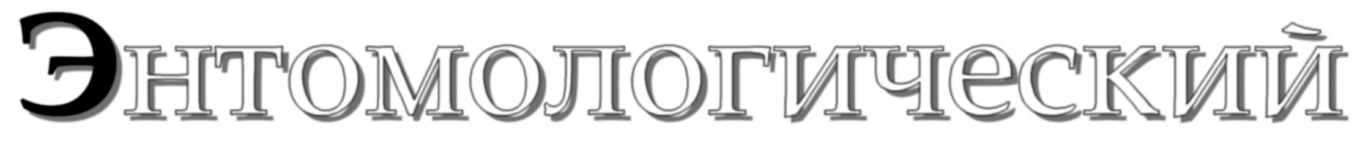 \\ БromieTeris
}

\section{CAUCASIAN ENTOMOLOGICAL BULLETIN}

\section{Том 1. Вып. 2 \\ Vol. 1. No. 2}

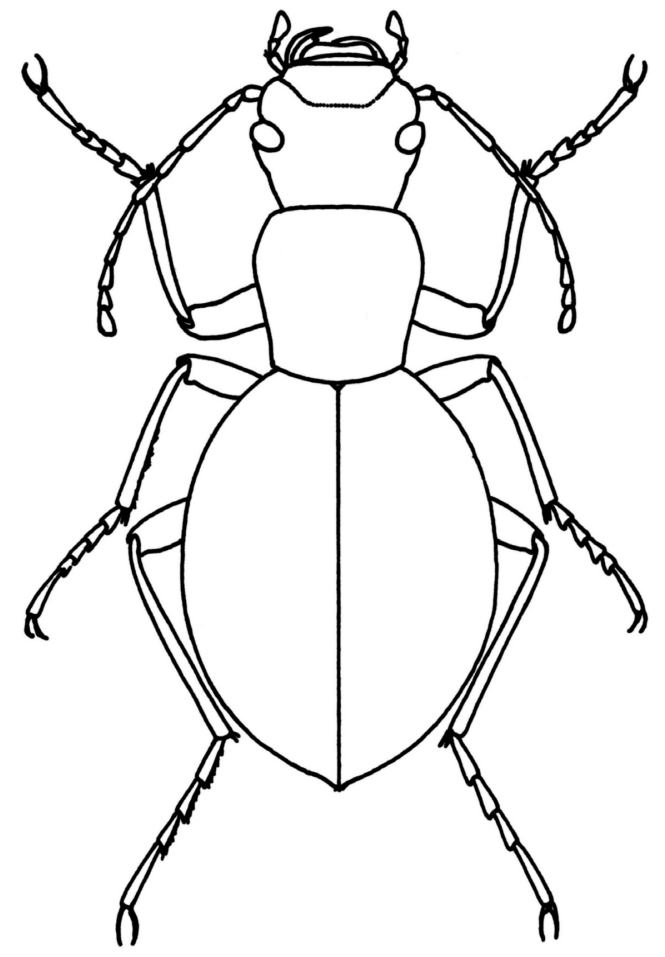

$$
\begin{gathered}
\text { Ростов-на-Аону }- \text { Москва } \\
2005
\end{gathered}
$$


К познанию систематики домгоносиков трибы Cleonini (sensu lato). 1. Pоды Pseudocleonus Chevrolat, 1873, Cleonis Dejean, 1821, Adosomus Faust, 1904, Cyphocleonus Motschulsky, 1960 и Xeradosomus gen. n. (Coleoptera: Curculionidae, Lixinae)

\title{
Towards the knowledge of the systematic of a weevil tribe Cleonini (sensu lato). 1. Genera Pseudocleonus Chevrolat, 1873, Cleonis Dejean, 1821, Adosomus Faust, 1904, Cyphocleonus Motschulsky, 1960 and Xeradosomus gen. $\mathbf{n}$. (Coleoptera: Curculionidae, Lixinae)
}

\author{
Ю.Г. Арзанов \\ Yu.G. Arzanov
}

Южный научный центр РАН, а/я 3318, Ростов-на-Аону 344092 Россия

Southern Scientific Center of RAS, PO Box 3318, Rostov-on-Don 344092 Russia, E-mail: arzanov@mmbi.krinc.ru

Ключевые слова: Curculionidae, Lixinae, Pseudocleonus, Cleonis, Adosomus, Cyphocleonus Xeradosomus, новый роА, новые подрода, опреАелительная таблица, эндофалмус, терминалии самок, сперматека.

Key words: Curculionidae, Lixinae, Pseudocleonus, Cleonis, Adosomus, Cyphocleonus, Xeradosomus, new genus, new subgenera, key, internal sac, female genitalia, spermatheca.

Резюме. На основании изучения внешних морфологических признаков, строения эндофалиусов и терминамий самок описан новый род Xeradosomus gen.n. (типовой виА Cleonus samsonovi Gebler, 1845), 2 подрода в роде Pseudocleonus (Neopseudocleonus subgen. n., типовой виА Curculio grammicus Panzer, 1789 и Asiacleonus subgen. n., типовой виА Cleonus dauricus Gebler, 1830) и по 1 новому подроду в родах Adosomus (Pseudoadosomus subgen.n., типовой виА Cleonus granulosus Mannerheim, 1825) и Cyphocleonus (Neocyphocleonus subgen.n., типовой виА Curculio dealbatus Gmelin, 1790).

Abstract. Based on the study of external morphological characters, the structure of male internal sac, and female genitalia, the following new taxa are described: Xeradosomus gen.n. (type species Cleonus samsonovi Gebler, 1845), Pseudocleonus (Neopseudocleonus) subgen. n. (type species Curculio grammicus Panzer, 1789), Pseudocleonus (Asiacleonus) subgen. n. (type species Cleonus dauricus Gebler, 1830), Adosomus (Pseudoadosomus) subgen.n. (type species Cleonus granulosus Mannerheim, 1825), and Cyphocleonus (Neocyphocleonus) subgen.n. (type species Curculio dealbatus Gmelin, 1790).

\section{Введение}

В настоящее сообщение включены роды центрацьной группы трибы Cleonini (sensu lato), характеризующиеся сросшимися коготками, широкими мапками с более ики менее развитыми войлочными подошвами, УАлиненным 2-м чмеником жгутика усика, а также тем, что все они трофически связаны с растениями семейства Asteraceae. Предварительные Аанные о таксономической структуре трибы Cleonini, развитие которой происходит на сложноцветных, нами опубликованы ранее [Арзанов, 2004].

В определительной таблице трибы Cleonini [TepМинасян,1988] родыдолгоносиков с широкими мапками рассматриваются как обособленная группа, куда, помимо Pseudocleonus Chevrolat 1873, Cleonis Dejean, 1821, Adosomus Faust, 1904, Cyphocleonus Motschulsky, 1860, включены еще Liocleonus Motschulsky, 1860 и Xanthochelus Chevrolat, 1873. При этом Ава послеАних рода в этом сосеАстве оказались явно случайно, так как при кажущейся бцизости по оАним признакам значительно уАалены по Аругим [Арзанов, 2004].

\section{Материамы и методы}

Материалом Аля настоящих исследований послужили богатейшие материалы Зоологического института РАН (Санкт-Петербург) и собственные сборы автора на юге и юго-востоке европейской части России.

Крометрадиционныхморфологическихпризнаков, используемых в большинстве таксономических работ по Аолгоносикообразным жукам, нами изучено строение энАофалцусов, гениталий и терминалий самок, которые Аают значительные положительные результаты в наАродовой систематике. Препараты эндофаллусов изготавливались по разработанной ранее методике [Арзанов, 2003], изучение гениталий и терминалий самок проходило на временных глицериновых препаратах.

\section{Резумьтаты и обсужАения}

\section{Pseudocleonus Chevrolat, 1873} Рис. 1-41

Pseudocleonus Chevrolat, 1873: 88.

Pseudocleonus: Faust, 1904: 228 (pro subgen. Mecaspis).

Pseudocleonus: Тер-Минасян, 1988: 64.

= Oosomus Motschulsky, 1860: 540 . 


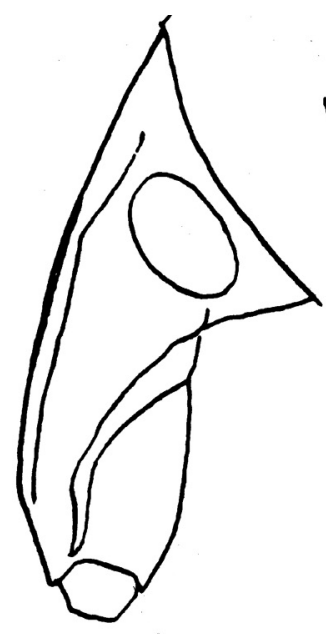

1

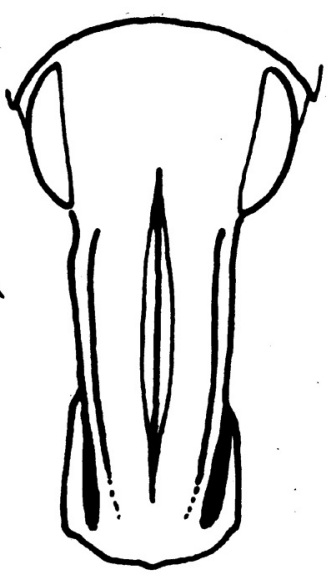

2

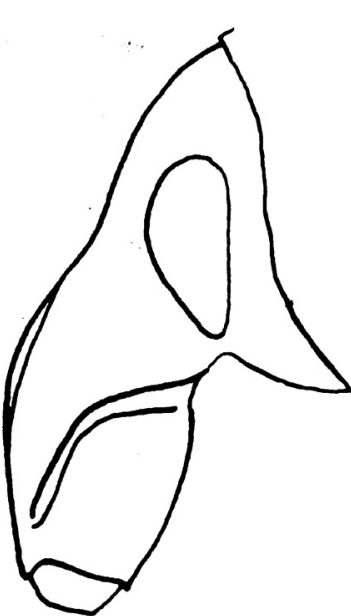

3

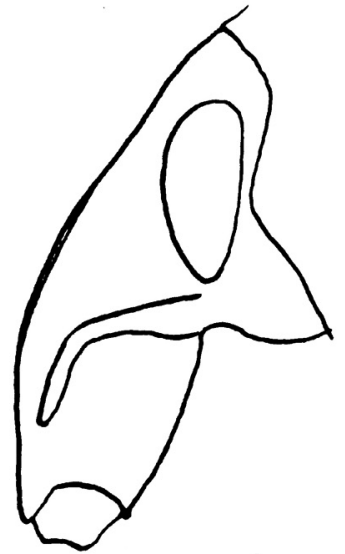

4

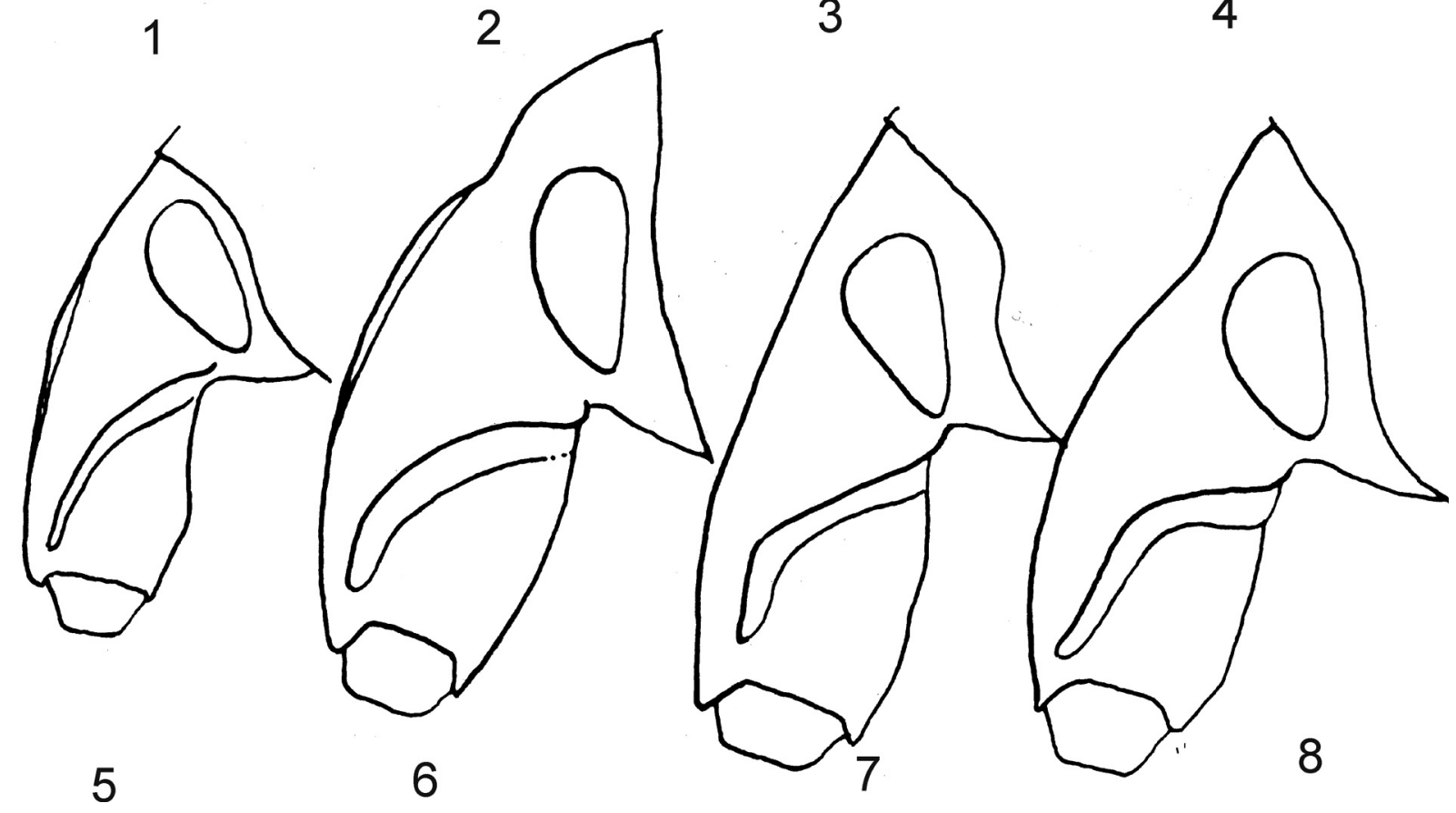

Рис. 1-8. Головотрубка (виА сбоку и сверху) Pseudocleonus Chevrolat.

1-7 - вид сбоку, 8 - вид сверху. 1, 8 - Ps. cinereus; 2 - Ps. dauricus; 3 - Ps. marginicollis; 4 - Ps. grammicus; 5 - Ps. taciturnoides; 6 - Ps. iskenderi; 7 - Ps. guldarensis.

Figs. 1-8. Rostrum (side view and from above) Pseudocleonus Chevrolat.

1-7 - side view, 8 - from above. 1, 8 - Ps. cinereus; 2 - Ps. dauricus; 3 - Ps. marginicollis; 4 - Ps. grammicus; 5 - Ps. taciturnoides; 6 - Ps. iskenderi; 7 - Ps. guldarensis.

Типовой виА. Curculio costatus Fabricius, 1787 (= Curculio cinereus Schrank, 1781), по первоначацьному обозначению.

Таксономические замечания. Мочульским [Motschulsky, 1860] в определительной таблице описан Oosomus, типовым видом которого бым указан Curculio costatus Fabricius, 1787 (= Cleonus cinereus Schrank, 1781). У Мочумьского новый род помещен в группу роАов, у которых Аорсацьная сторона головотрубки имеет меАиамьный кимь или возвышенную поверхность, моб выпукмый, 1-й чменик жгутика усика бомьше 2-го и переАние голени без Алинных волосков. Бмижайшими к нему родами автором рассмотрены Rabdorhynchus
Motsch., 1860 и Pachycerus Schoenh., 1826, которые, в отмичие от Oosomus, имеки вытянутое тело (боками наАкрылий не закруглены) и короткую рукоять усиков. В Аальнейшем Шевроля [Chevrolat, 1873] отметиц, что описанный Мочульским род Oosomus является омонимом к роду, установленному Шонхером [Schoenherr, 1826] в трибе Oosomini из подсемейства Enthiminae и описал род Pseudocleonus (= Oosomus Motschulsky, 1860), типовым видом которого установим Cleonus cinereus. В работе по обзору «Cléonines vrais» Фауст [Faust, 1904] помещает Pseudocleonus на правах подрода в род Mecaspis Schoenh., 1826 [c.l., стр. 228], а в каталоге родов [c.l., стр. 279] приводит название Pseudocleonus без указания его таксономического статуса, хотя и рас- 
полагает рода Mecaspis и Pseudocleonus в непосредственной близости. ОАнако в общей таблице родов [c.l., стр.181-190] эти роды сильно удалены Аруг от Аруга, при этом Pseudocleonus сближен к Stephanocleonus Motsch., 1860, Anisocleonus Faust, 1904 (=Asinocleonus), Eumecops Hochh., 1851, Atactogaster Faust, 1904 и Ар., a Mecaspis помещен в соседстве с Trachydemus Chevr. 1873, Leucomigus Motsch., 1860, Cyphocleonus Motsch., 1860 и Coniocleonus Motsch., 1860. У Рейттера [Reitter, 1912] в определительной таблице род Pseudocleonus расположен рядом с Месаspis и отличается от него закругленными выпуклыми надкрыльями и отсутствием заметных бугорков на вершине. Тер-Минасян [1988] не подАерживает точку зрения Рейттера на положение Pseudocleonus в системе Cleonini и симьно удацяет эти роды Аруг от Аруга на основании строения члеников заАней мапки. При этом Pseudocleonus ею отнесен к группе родов с широкими мапками (Xanthochelus, Cleonis, Cyphocleonus, Adosomus и Ар.), а Mecaspis к группе с узкими мапками, у которых 2-й чменик симьно уАлинен и значительно превосходит Алину 3-го (Isomerus Motsch. 1860, Stephanocleonus, Coniocleonus и Ар.). Мнение ТерМинасян о ближайшем окружении Pseudocleonus подтвержАается и его трофикой, включающей растения из семейства сложноцветных (Asteraceae), в то время как Mecaspis развивается на зонтичных (Apiaceae). По особенностям внешней морфологии роА Pseudocleonus в определительной таблице Тер-Минасян [1988] Аелится на подроды в зависимости от степени выпукмости промежутков наАкрылий. Следует, однако, отметить, что автор [c.l., стр. 9] в систематическом указателе видов не разбивает Pseudocleonus на подроды. В последнем родовом каталоге палеарктических Аолгоносикообразных жуков [Alonso-Zarasaga et Lyal, 1999] поддержано деление рода на 2 подрода - Pseudocleonus и Phryganocleonus.

Описание. Головотрубка уАлиненная, толстая, с закругленными боками без следов боковых кантов, слабо дорсовентрально изогнута, с коротким и слабым медиальным килем (Ps. dauricus, Ps. marginicollis, Ps. taciturnoides) или ограниченабоковымикантами(Ps.cinereus);усиковыеборозАки продолжены впереА от места прикрепления усиков и сужены к вершине, с вентральной стороны головотрубки у основания они широкие, не соединяются Аруг с Аругом; медиальный кимь на головотрубке узкий (Ps. cinereus) или киль более или менее высокий, межит на возвышенной поверхности и ограничен по сторонам глубокими бороздками и матеральные кили более или менее явственные (Ps. gramineus) или без возвышения, ограниченного широкими боковыми бороздками, но без боковых кантов (Ps. iskanderi и Ps. guldarensis).

Вентральная сторона головотрубки гладкая без килей и бороздок или с тонкими нитевидными и короткими бороздками, ограничивающими субментум по сторонам, у Ps. grammicus также с крупной точкой в базальной части. Эпистом слабый, не отделен от Аорсальной поверхности головотрубки, более или менее треугольный, у Phryganocleonus он короткий, сильно поперечный и ограничен по заднему краю тонким поперечным валиком.

Прементум равной Алины и ширины, его передний край прямой (Ps. grammicus) или со слабой выемкой (Ps. cinereus, Ps. iskanderi); бока с узкой перетяжкой у переднего края, Аопастевидно выпукмы и равномерно слабо расширены к основанию, Аалее с небольшой выемкой у основного угла и слабым дуговидным выступом в основании (у Ps. cinereus) или сразу за перетяжкой с небольшой, но явственной цопастью; Аалее к основанию бока равномерно закруглены и их основной край полукруглый (Ps. grammicus, Ps. iskanderi).

Постментум стебельчатый, по переднему краю прямой, без выемки, в базальной части отделен швом от нижней стороны головотрубки (Ps. cinereus).

Максилма широкая (Ps. grammicus, Ps. iskanderi) или уАлиненная (Ps. cinereus). Аациниальные зубцы двух типов: 3 вершинных шиловидных и 4 крупных крючковидных по внешнемукраю. Галеальный ряд из 3-х крупных крючковидных, но меньших, чем мациниальные (у Ps. grammicus), или 4-х шиловидных прямых (Ps. cinereus). Щетинки на вершине и внешней стороне равные, немного короче кациниальных зубцов (Ps. grammicus) или более Алинные в вершиной части (Ps. cinereus). Пальпигер поперечный, уже 1-го чменика щупика (Ps. grammicus) или удлиненный, в 1.5 раза Алиннее ширины (Ps. cinereus), покрыт густыми короткими щетинками по наружному краю. 1-й чменик щупика квадратный, 2-й немного поперечный, 3-й - узкий, уАлиненный. ГАаза широко овальные, не заужены к нижней части головы (Ps. cinereus) или уАлиненные, зауженные к нижнему краю, по переднему краю слабо выпуклые или прямые (остальные виды).

Усики. 1-й чменик жгутика в 2 раза больше 2-го (Ps. dauricus, Ps. guldarensis, Phryganocleonus), более чем в 2 раза больше 2-го (Ps. grammicus, Ps. taciturnoides) и мишь в 1.3-1.5 раза больше 2-го (Ps. cinereus, Ps. marginicollis). Булава коротко овальная, Алина в 1.6-1.7 раза больше ширины (Ps. dauricus, Ps. cinereus), или уАлиненная, Алина более чем в 2 раза больше ширины (Ps. marginicollis, Ps. taciturnoides).

Переднеспинка с закругленными боковыми сторонами, резкой преАвершинной перетяжкой, хорошо заметной на боках, с сильными заглазничными копастями, Аорсальная сторона в Авойной точечности с тонким и слабым медиальным килем; коксальная часть переднегруди в центре широко вАавлена, со слабыми предкоксальными выпуклостями (Ps. dauricus). Медиальный киль широкий и плоский со слабыми, но явственными заглазничными мопастями; прекоксальная часть переднегруди в центре не вдавлена, без прекоксальных бугров (Ps. cinereus). Переднеспинка с прямыми сторонами Ао первой трети, Аалее постепенно сужена к вершине, дорсальная часть плоская, заглазничные мопасти явственные, медиальный киль слабый мишь в первой половине, задний край прямой (Ps. grammicus, Ps. marginicollis).

Надкрылья у основания не шире переднеспинки, без плечевых бугорков. Поверхность надкрыльев и переднеспинки с Аанцетовидными или щетинковидными чешуйками.

Щиток явственный Аишь у видов подрода Phryganocleonus.

Ноги. Голени по внутренней стороне без шипов. Аапки широкие, снизу с войлочными подошвами, 2-й чменик равен 3-му. Коготки сросшиеся.

Эндофалмус. По строению базо-дорсального выступа выделяются 3 группы. К первой относится Аишь Ps. cinereus, у которого базо-дорсальный выступ крупный и широкий, слабо возвышен наА медиальной областью, ко второй группе относятся Ps. taciturnus и Ps. dauricus, у которых базо-дорсальный выступ узкий и уАлиненный, возвышен наА медиальной областью с острой заостреннной вершиной, к третьей $-P s$. marginicollis, Ps. grammicus и Ps. guldarensis, имеющие уАлиненный, узкий базо-дорсальный выступ с разАвоенной вершиной. Базо-дорсальные бугры имеются мишь у Ps. guldarensis, базо-вентральные бугры имеются у всех видов, но степень их развития различная. Медиальная область сильно выпукцая у P. cinereus и менее выпукцая у P. grammicus. Медио-дорсальные бугры слабо выдающиеся, но явственные, у Р. grammicus развиты не только проксимальные, но и дистальные (что хорошо отличает его от $P$. cinereus), медио-латеральные бугры сильно увеличены и образуют один крупный бугор, медио-ла- 


$$
\begin{aligned}
& \text { Yrop } \\
& \text { You }
\end{aligned}
$$




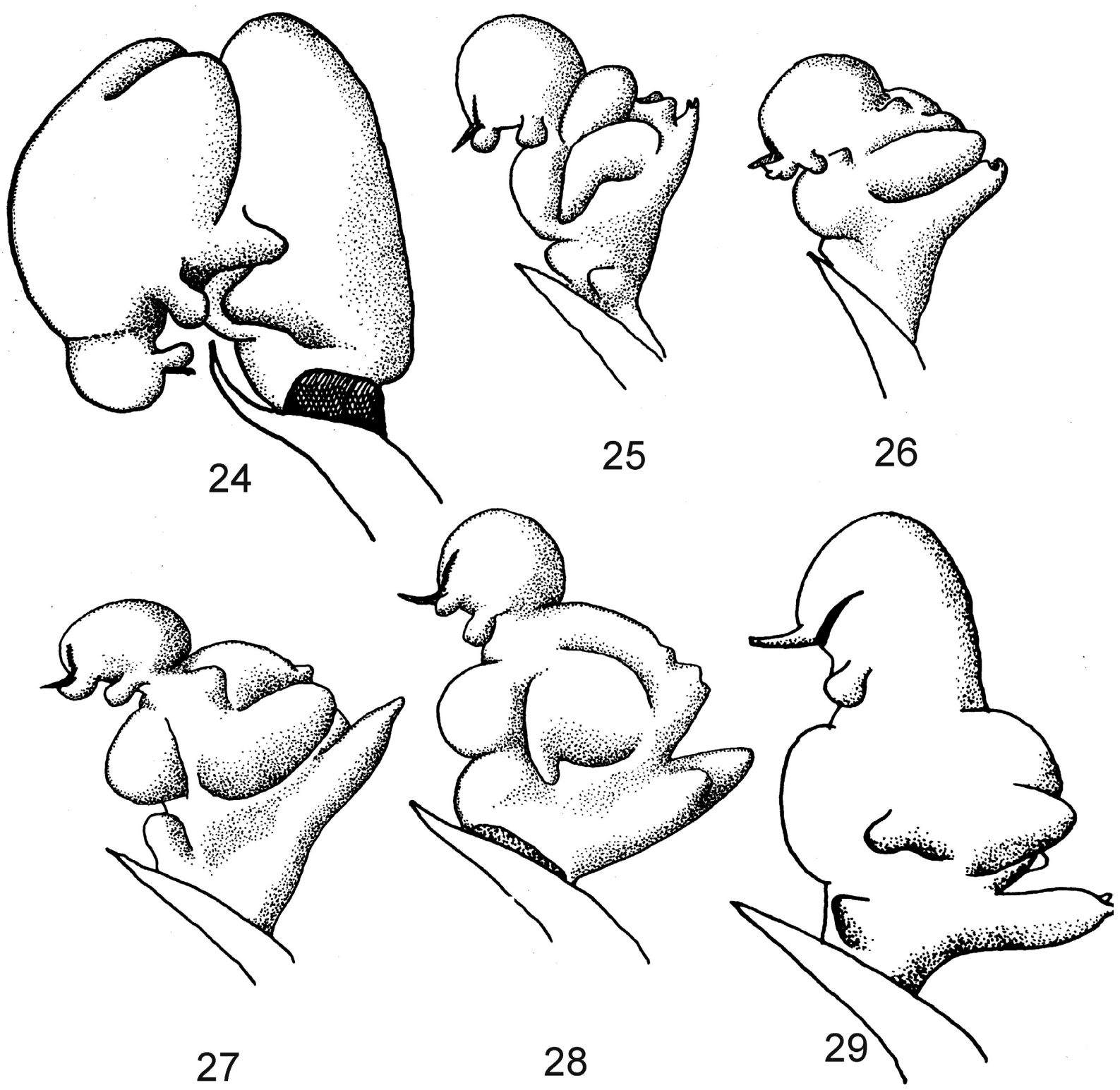

Рис. 24-29. Эндофалиус Pseudocleonus Chevrolat, общий виА

24 - Ps. cinereus; 25 - Ps. grammicus; 26 - Ps. marginicollis; 27 - Ps. dauricus; 28 - Ps. taciturnoides; 29 - Ps. guldarensis.

Figs. 24-29. Internal sac Pseudocleonus Chevrolat, appearance

24 - Ps. cinereus; 25 - Ps. grammicus; 26 - Ps. marginicollis; 27 - Ps. dauricus; 28 - Ps. taciturnoides; 29 - Ps. guldarensis.

Pseudocleonus (Pseudocleonus) Chevrolat, 1873 (Рис. $1,8,13,16,22,24,30,36)$

= Oosomus Motschulsky, 1860: 540 (non Schoenherr, 1826).

В данный подрод включен мишь Pseudocleonus cinereus Schrank, 1781.

Описание. Головотрубка уАлиненная, ограничена боковыми кантами; усиковые бороздки продолжены впереА от места прикрепления усиков и сужены к вершине, меАиальный киль узкий. Вентральная сторона головотрубки с тонкими нитевиАными и короткими борозАками, ограничивающими субментум. Эпистом короткий, не отделен от Аорсальной поверхности головотрубки, более или менее треугольный.
Прементум со слабой выемкой, с узкой перетяжкой у переднего края, боковой край мопастевиАно выпукмый и равномерно слабо расширен к основанию, Аалее с небольшой выемкой у основного угла и слабым Ауговидным выступом в основании.

Максимла уАлиненная. Аациниальные зубцы Авух типов: 3 вершинных шимовидных и 4 крупных крючковиАных по внешнему краю. Галеальный ряА из 3-х крупных крючковидных, меньших, чем мациниальные, и 4-х шиловидных прямых зубцов. Пальпигер уАлиненный, в 1.5 раза Алиннее ширины, с густыми короткими щетинками по наружному краю. 1-й членик щупика квадратный, 2-й немного поперечный, 3-й - узкий, уАлиненный.

ГАаза широко овальные, не заужены к нижней части го$\Lambda$ овы.

Усики. 1-й членик жгутика в 1.3-1.5 раза больше 2-го. Бумава коротко овацьная, Алина в 1.6-1.7 раза больше ширины. 


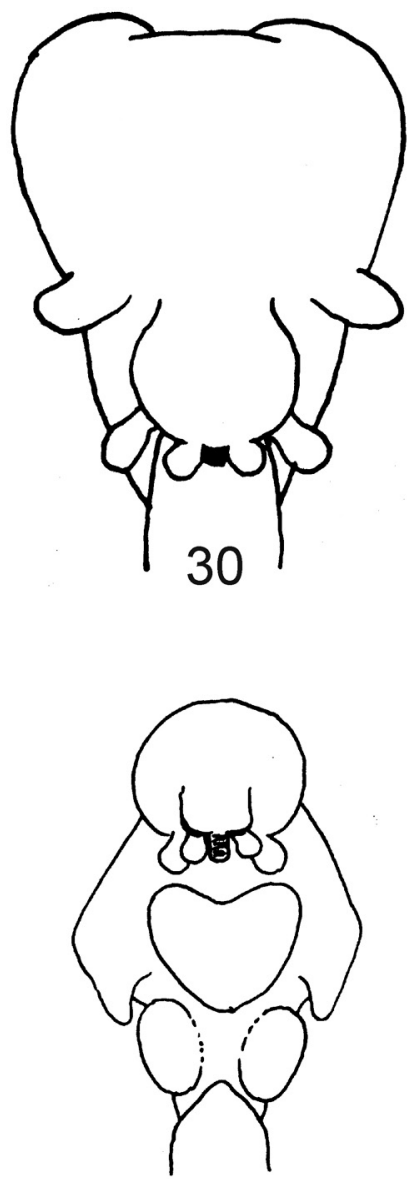

34

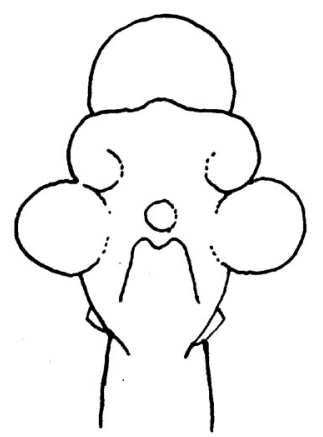

38

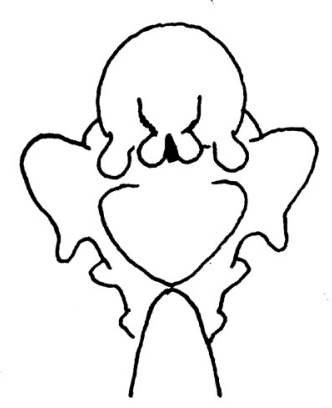

31

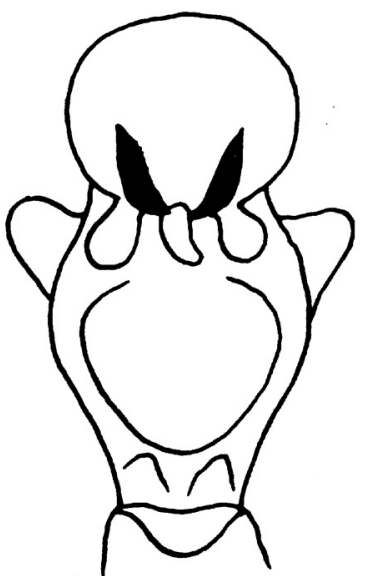

35

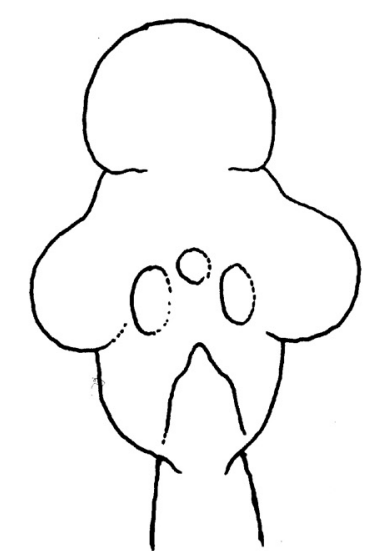

39

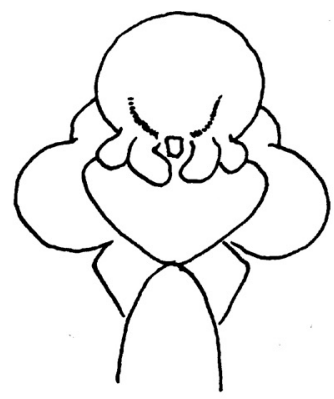

32
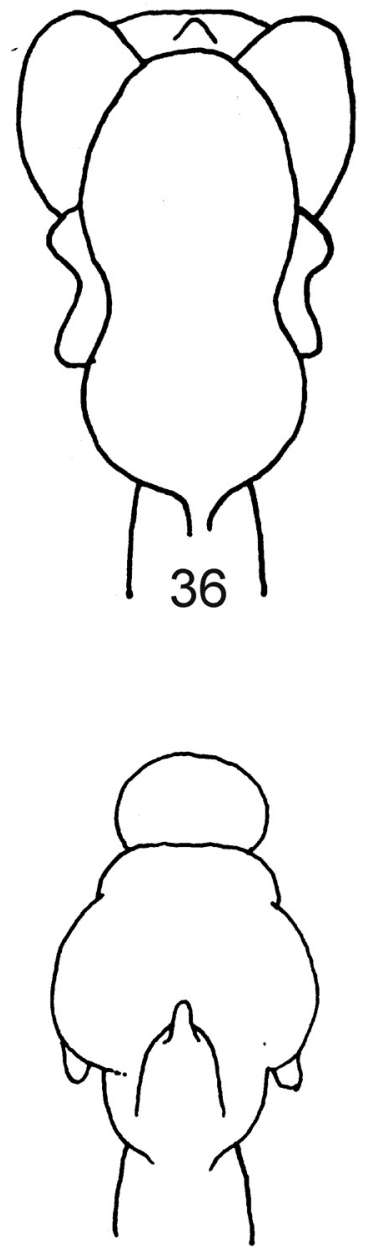

40
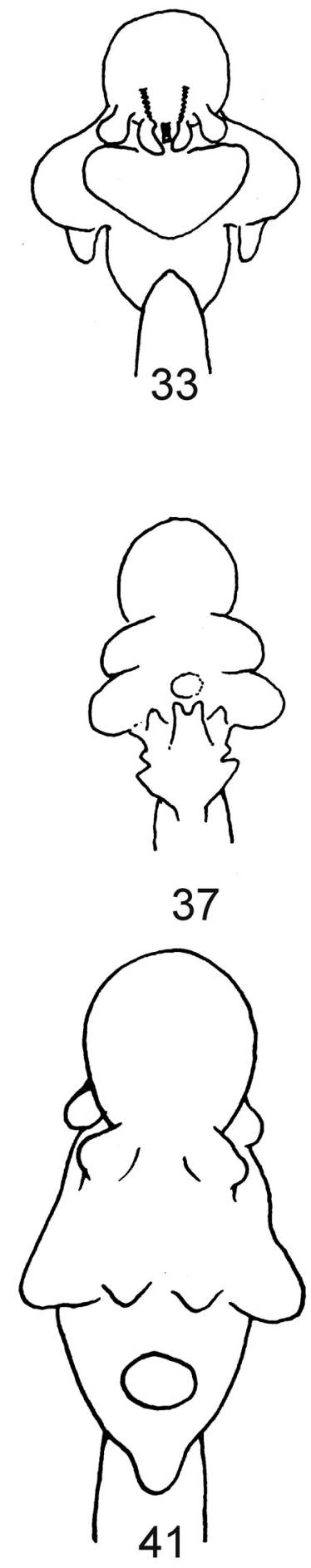

Рис. 30-41. Эндофалиус Pseudocleonus Chevrolat, вид спереди и сзади

30-35 - вид спереди, 36-41 - вид сзади. 30, 36 - Ps. cinereus; 31, 37 - Ps. grammicus; 32, 38 - Ps. marginicollis; 33, 39 - Ps. dauricus; 34,40 - Ps. taciturnoides; 35, 41 - Ps. guldarensis.

Figs. 30-41. Internal sac Pseudocleonus Chevrolat, ventrale view and dorsal view

30-35 - ventrale view, 36-41 - dorsal view. 30, 36 - Ps. cinereus; 31, 37 - Ps. grammicus; 32, 38 - Ps. marginicollis; 33, 39 - Ps. dauricus; 34 , 40 - Ps. taciturnoides; 35, 41 - Ps. guldarensis. 
ПереАнеспинка с широким и плоским медиальным ки^ем; прекоксальная часть переднегруди без бугров.

Щиток не виден.

Эндофалмус. Базо-дорсальный выступ крупный и широкий, слабо возвышен наА меАиальной областью. Медиальная область сильно выпуклая, медио-дорсальные бугры развиты, медио-латеральные бугры сильно увеличины и образуют один крупный бугор, медио-латеральные Аистацьные бугры хорошо развиты. Апикацьная область небольшая.

Вентральная спикула. Аамелма ромбовидная, равной Алины и ширины, с кАиновиАно расхоАящимися ветвями, на вершине которых расположены удлиненно-овальные Аистальные мопасти. Манубриум ровный, прямой, равен Алине камелиы, с заостренной вершиной.

Сперматека с широким слабо выступающим nodulus, c характерной гофрировкой, collum конусовидный с широким основанием, ramus широкий с наАстройкой. Cornu прямой от основания и резко изогнут в середине, постепенно заострен к вершине, вершина узкая, острая.

ЯйцекмаА. Коксит короткий, конусовидный, более ими менее сильно сужен к вершине, стилус короткий, с короткими хетами на вершине, Алина его в 1.5 раза больше ширины.

Распространение. Европа, Крым, Кавказ, Казахстан, Туркменистан, ААтай, Северо-Западный Китай.

Pseudocleonus (Neopseudocleonus) subgen. n.

Рис. 3, 4, 10-11, 15, 17, 20-21, 25-26, 31-32, 37-38

Типовой виА. Curculio grammicus Panzer, 1789.

В Аанный подрод вкАючены P. grammicus (Panzer, 1789) и $P$. marginicollis (Fahraeus, 1842).

Описание. Головотрубка уАлиненная, толстая, с закругленными боками без следов боковых кантов, слабо изогнута дорсовентрально, медиацьный киль более или менее высокий, межит на возвышенной поверхности и ограничен по сторонам глубокими борозАками, матеральные кили более или менее явственные. Субментум с тонкими нитевидными и короткими борозАками и крупной точкой в базальной части.

Максимла широкая. Аациниальные зубцы двух типов: 3 вершинных шиловидных и 4 крупных крючковидных по внешнему краю. Галеальный ряд из 3-х крупных крючковидных зубцов, но меньших, чем мациниальные. Щетинки на вершине и внешней стороне равные, немного короче мациниальных зубцов. Пахьпигер поперечный, уже 1-го членика щупика. 1-й чиеник щупика квадратный, 2-й - немного поперечный, 3-й - узкий, УАлиненный.

ГАаза уАлиненные, зауженные к нижнему краю, по переАнему краю слабо выпукмые или прямые.

Усики. 1-й членик жгутика в 1.5-2 раза больше 2-го. Булава уАлиненная, Алина более чем в 2 раза больше ширины.

ПереАнеспинка с прямыми сторонами Ао первой трети, Аалее постепенно сужена к вершине, основной край прямой; Аорсацьная сторона плоская, медиацьный киль слабый, раз-

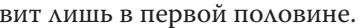

Надкрыхья УАлиненно овальные.

Щиток не виАен.

Эндофамкус с уАлиненным узким базо-дорсальным выступом с разАвоенной вершиной. МеАиальная область слабо выпукмая. Медио-дорсальные бугры (проксимальные) слабо выдаются, медио-латеральные бугры сильно увеличены и образуют один крупный бугор, медио-латеральные Аистальные бугры выражены. Апикацьная область крупная, круглая, с апикацьными, крупными периаггоноподиацьными буграми.

Вентральная спикула. Аамемла уАлиненная (Ps. marginicollis) ики поперечная (Ps. grammicus) с почти парацАельными сторонами, с равной Алиной и шириной, ветви ее ровные или слабо утонченные к вершине, от середины с уАлиненно-овальными дистальными Аопастями, внутренняя часть

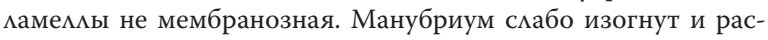
ширен у вершины (Ps. grammicus) или прямой, слабо сужен к вершине (Ps. marginicollis).

Сперматека имеет короткий, но симьно сферически выступающий nodulus, collum - конусовидный и короткий, ramus широкий, немного выступающий, отодвинут от collum на Алину своего диаметра. Cornu изогнутый от основания, с прямыми сторонами, слабо зауженными у вершины (Ps. marginicollis) ими коленообразно изогнутый от основания, к вершине симьно заужен и заострен (Ps. grammicus).

ЯйцеклаА с коротким кокситом, конусовидный, более ими менее симьно сужен к вершине, стилус короткий, Алина его в 1.5 раза больше ширины, не пигментирован.

Распространение. СреАняя и Южная Европа, Крым, Кавказ.

\section{Pseudocleonus (Asiacleonus) subgen. n.}

Рис. 2, 5, 9, 14, 19, 27-28, 33-34, 39-40

\section{Типовой виА. Cleonus dauricus Gebler, 1830.}

В Аанный подрод вкцючены Pseudocleonus dauricus (Gebler, 1830), Ps. taciturnoides L. Arnoldi, 1956, которых еще Арнольди [1956] считал наиболее близкими видами. При описании Ps. taciturnoides Арнольди указал его эндемиком верхней зоны кеса и субальпийской зоны Ферганского хребта, занимающего высоты от 1800-2200 м наА уровнем моря и, по всей видимости, явцяющимся викарным аля Ps. dauricus, который не проникает на юг далее Центрального Тянь-Шаня, а на северо-западе Аоходит до Саратова.

Описание. Головотрубка уАциненная, толстая, с закругленными боками без слеАов боковых кантов, слабо изогнута Аорсовентрально, с коротким и слабым медиальным килем.

ГАаза удииненные, зауженные к нижнему краю, по переАнему краю слабо выпукмые ими прямые.

Усики. 1-й членик жгутика в 2 и более раза больше 2-го. Булава коротко овальная, Алина в 1.6-1.7 раза больше ширины (Ps. dauricus) ими уалиненная, более чем в 2 раза больше ширины (Ps. taciturnoides).

ПереАнеспинка с резкой преАвершинной перетяжкой, хорошо заметной на боках, с сильными заглазничными мопастями, Аорсальная сторона в Авойной пунктировке с тонким и слабым медиальным килем; коксальная часть переднегруди в центре широко вАавлена, со слабыми прекоксальными выпукмостями.

Щиток не заметен.

Эндофамкус с узким и уАлиненным базо-дорсальным выступом, возвышенным наА меАиальной областью острой вершиной.

Вентральная спикула. Аамелма слабо удииненная, ее ветви кАиновиАно расходящиеся; Аистальные мопасти широкие и уАлиненные, расположены по внутренней стороне ветвей, с паралмельными сторонами, манубриум прямой, постепенно расширен к вершине.

Сперматека наиболее близка по строению к Ps. cinereus, но еe cornu значительно уже, а ramus широкий в основании.

Распространение. СреАняя и Южная Европа, Узбекистан, А^тай, Забайкацье. 
Pseudocleonus (Phryganocleonus) Arnoldi, 1956 Рис. 6-7, 12, 18, 29, 35, 41

Phryganocleonus Arnoldi, 1956: 682 (pro subgen. Pseudocleonus)

Типовой вид. Pseudocleonus guldarensis L. Arnoldi, 1956 (по первоначальному обозначению).

В Аанный подроА вкмючены Ps. guldarensis L. Arnoldi, 1956, Ps. iskanderi L. Arnoldi, 1956, Ps. tadzhika L. Arnoldi, 1956

Как отмечал Арнольди [1956], первоначально таксону Phryganocleonus он придавал родовой статус, так как основывац свои преАставцения на изучении еАинственного известного на тот период вида Ps. guldarensis. При обнаружении еще нескольких видов, близких к Ps. guldarensis, формирующих послеАовательный морфологический ряА и в различной степени укмоняющихся от виАов Pseudocleonus (s. str.), он пересмотрел свои взгляды на Phryganocleonus и закрепи за ним статус подрода. При описании Phryganocleonus Арнольди отмечац, что новый подрод отличается от Pseudocleonus (s. str.) сравнительно толстым и коротким жгутиком, 1-й членик которого не более, чем в 1.7 раза больше ширины у вершины, узкой и острой булавой, головотрубкой, не суженной к вершине, отсутствием треугольного эпистома и строением надкрылий, имеющих выступающие нечетные промежутки. Все представители Phryganocleonus распространены в западной половине Гиссарского хребта и приурочены к горным ксерофитным мандшафтам на высотах свыше 2600 м.

Описание. Головотрубка удлиненная, толстая, с закругленными боками без следов боковых кантов, слабо изогнута Аорсовентрально, с коротким, более или менее высоким медиальным килем, без возвышения, ограниченного широкими боковыми борозАками, без боковых кантов. Эпистом сильно поперечный и ограничен по заднему краю тонким валиком.

ГАаза удАиненные, зауженные к нижнему краю, по переАнему краю слабо выпукмые или прямые.

Усики. 1-й членик жгутика в 2 раза больше 2-го. Булава УАлиненная, Алина более чем в 2 раза больше ширины.

Переднеспинка с сильными заглазничными мопастями, Аорсальная сторона в Авойной точечности с тонким и слабым медиальным килем.

Щиток явственный.

Эндофалмус с уАлиненным, узким базо-дорсальным выступом с разАвоенной вершиной. Базо-дорсальные бугры имеются Аишь у Ps. guldarensis, базо-вентральные бугры имеются у всех виАов, но степень их развития различная.

Вентральная спикука. Аамелма слабо уАлиненная, с почти паралмельными Аистально и сходящимися кАиновидно к основанию сторонами, равной Алины и ширины, ветви ее изогнуты в средней части, слабо утонченные к вершине, у вершины с уАлиненно-треугольными Аистальными мопастями. Манубриум в 1.5 раза короче мамелмы, ровный, слабо изогнут, у вершины с топоровидным расширением.

Сперматека с коротким сферически выступающим nodulus, collum узкий, конусовидный, ramus широкий, конусовидный. Cornu коленовидно изогнутый в средней части и Аалее к вершине постепенно зауженный.
Распространение. Таджикистан, Узбекистан.

\section{ОПРЕАЕАИТЕАЬНАЯ ТАБАИЦА ПОАРОАОВ}

1 (6) Щиток не виден сверху, скрыт основанием надкрыльев, надкрылья более или менее овальные, промежутки плоские.

2 (3) ГАаза коротко овальные. Аорсальная сторона головотрубки от места прикрепления усиков сужена впереА, ограничена с боков выступающими кимями, меАиальный киль головотрубки и переАнеспинки плоский и широкий. Эндофамкус с крупным высоким базо-вентральным выступом и крупной медиальной областью..................................Pseudocleonus Chevrolat

3 (2) ГАаза удминенные.

4 (5) 1-й членик жгутика усиков не более чем в 1.5 раза больше 2-го. Основной край переднеспинки прямой, боковые стороны с полосой из густых светлых чешуек. Базо-дорсальный выступ эндофалмуса Авухвершинный... Neopseudocleonus subgen. $\mathbf{n}$.

5 (4) 1-й членик жгутика усиков в 2 раза больше 2го. Основной край переднеспинки со слабым выступом в середине, бока переднеспинки без густых светлых полос. Базо-дорсальный выступ эндофаллуса одновершинный. Asiacleonus subgen. $\mathbf{n}$.

6 (1) Щиток явственный, хорошо заметен сверху, надкрылья УАлиненные, нечетные промежутки приподняты....................... Phryganocleonus L. Arnoldi

Изученный материам. Pseudocleonus dauricus (Gebler, 1830), Ps. cinereus (Schrank, 1781), Ps. grammicus (Panzer, 1789), Ps. iskanderi L. Arnoldi, 1956, Ps. taciturnoides L. Arnoldi, 1956, Ps. guldarensis L. Arnoldi, 1956 и Ps.. marginicollis (Fahraeus, 1842). Остались неизученными Ps. tadzhika L. Arnoldi, 1956, Ps. havtagensis Ter-Minassian, 1976 и Ps. ferghanensis TerMinassian, 1988.

Cleonis Dejean, 1821 Рис. $42-47$

Cleonis Dejean, 1821: 96.

Типовой виА. Curculio sulcirostris Linnaeus, $1767=$ Curculio piger Scopoli, 1763.

Cleonis: Dieckmann, 1983: 324.

=Eratus: Dejean, 1821: 96 .

= Ophis: Dejean, 1823: 96 (non Turton, 1807).

=Geomorus Schoenherr, 1823: 1141 .

=Cleonus Schoenherr, 1826: 145 .

=Xerobia Gistel, 1856: 373.

Таксономические замечания. Шонхером в 1823 году [Schoenherr, 1823] бым установлен род Geomonus Амя Curculio sulcirostris L., 1767, немного позже, в 1826 году, он устанавцивает Аля указанного вида род Cleonus Schoenherr, 1826, так как неверно понимает описанный ранее Аежаном [Dejean, 1821] род Cleonis. Следует отметить, что Аежан в этой же работе описывает еще Ава рода Eratus Dej., 1821 и Ophis Dej., 1821, позже сведенные в синонимы к Cleonis Dej., 1821.

В известной работе Мочульского [Motschulsky, 1860] род Cleonus (=Cleonis) вместе с Pleurocleonus и 


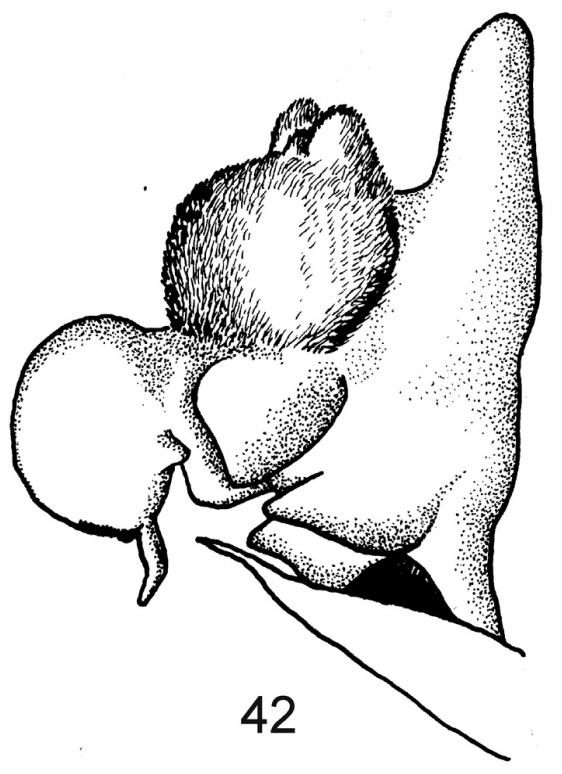

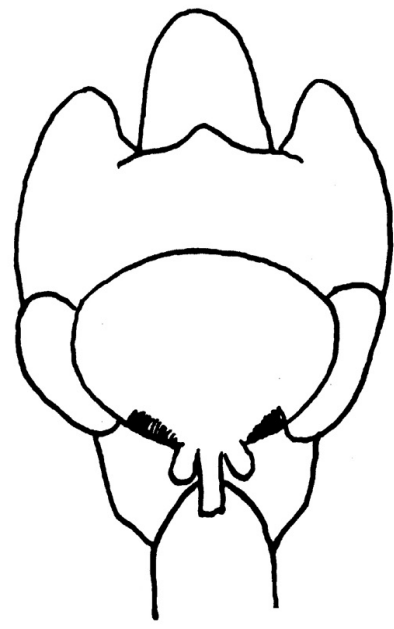

43

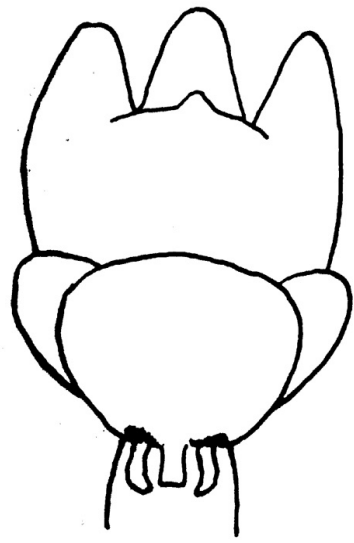

46
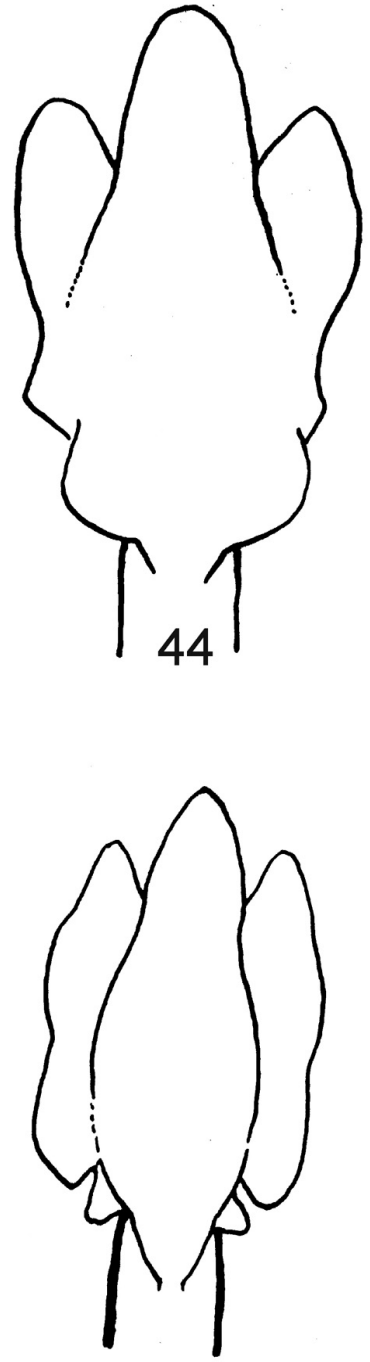

47

Рис. 42-47. Эндофамлус Cleonis Dejean

42-43 - общий виА, 44-45 - виА спереди, 46-47 - вид сзади. 42, 44, 46 - C. japonicus; 43, 45, 47 - C. neglectus Рис. 42-47. Internal sac Cleonis Dejean

42-43 - appearance, 44-45 - ventrale view, 46-47 - dorsal view. 42, 44, 46 - C. japonicus; 43, 45, 47 - C. neglectus

Liocleonus помещен в отдельную группу на основании особого строения Аорсальной стороны головотрубки. Аля этих родов характерна медиальная бороздка, ограниченная высокими катеральными килями (y Liocleonus имеется мишь борозАка). В Аальнейшем Шевроля [Chevrolat, 1873] помещает род Cleonus в сборную группу (=devision) «Cléonides vrais», куАа, кроме Cleonus, попало и большинство известных родов с медиальными килями на Аорсальной стороне головотрубки. Внутри «Cléonides vrais» Шевроля группирует роды по особенностям строения глаз. В группу с узкими, уАлиненными и паралмельносторонними глазами вкцючены, кроме Cleonus, также и Pachycerus, Rabdorhynchus, Mecaspis, Pseudocleonus, Cyphocleonus, Xanthochelus и Ар. У Фауста [Faust, 1904] род Cleonus занимает соседнее поможение с Adosomus, а близкий к нему Cyphocleonus и Xanthochelus от него удалены. При этом Xanthochelus и Pleurocleonus, сближенные к Cleonus по особеннос- тям строения головотрубки, отличаются от него крупными голыми пятнами на вентритах и уАлиненными узкими мапками, а Cyphocleonus, кроме того, не имеет заглазничных копастей. Рейттер [Reitter, 1912] роА Cleonus рассматривац в непосреАственной близости к Cyphocleonus и Adosomus, при этом границы межАу роАами считал Аостаточно нечеткими. В следующей работе Рейттер [Reitter, 1916] исправим эту «нечеткость», объединив их в один род Cleonus и придав им статус подродов на основании того, что эти таксоны объединяет наличие хорошо выраженных зерен на переднеспинке и основании надкрылий. При этом особенности киця на головотрубке рассматривались как признаки Аля разделения подродов. Следуя могике Рейттера, в род Cleonis Аолжен быть вкАючен также и Xanthochelus, причем в номинативный подрод? и Leucomigus в поАроА к Cyphocleonus (sensu [Reitter, 1916]). У Тер-Минасян [1988] сохранено положение родов, преАложенное 
в ранней работе Рейттера [Reitter, 1912], при этом она использовала ряд признаков, указанных предыдущими исследователями. Нахождение в роде Cleonis вида без явственного Авойного медиального киця на головотрубке (C. neglectus) в некоторой степени подтвержАает мнение Рейттера о крупном объединеном роде Cleonus (sensu [Reitter, 1916]), так как этот виА, имея явное сходство с известными видами рода Cleonis (C. pigra, C. japonicus), нарушает устоявшееся мнение о характерной особенности рода и должен быть рассмотрен, по всей видимости, в роде Cyphocleonus. ОАнако в таком случае род Cyphocleonus (sensu auct.) должен быть монолитным и не распадаться на отдельные группы, в противном случае таксону Cleonus (sensu Reitter) необходимо было бы повысить статус.

Описание. Головотрубка паралмельносторонняя, по Аорсальной стороне с медиальной бороздкой, ограниченной по сторонам килями, ее вентральная сторона с Авумя тонкими продольными бороздками, ограждающими субментум, более углубленными по Аистальному краю, соединенными у основания головотрубки и продолженными Аалее гулярным швом. Усиковые борозАки на вентральной стороне у основания головотрубки не соединены.

Прементум с прямым передним краем, крупной боковой Аопастью, серАцевидно сужен к основанию, с Авумя хетами по боковому краю с каждой стороны.

Постментум высокий, широкий, скабо стебельчатый, по обеим сторонам с рядом из 3-х щетинок.

Максимла с 5-6 крупными мациниальными зубцами и Алинными щетинками по всей поверхности, галеальный ряА зубцов не развит. Пальпигер Алинный, равен 3-м сильно поперечным членикам щупика, в Алинных щетинках по переднему краю.

ГАаза овальные, зауженные книзу.

Усики. Рукоять усиков слабо расширена к вершине, 1-й чменик жгутика усика равен 2-му или немного больше его, 3-6й - поперечные, 7-й - широко трапециевиАный, букава УАлиненно-овальная, немного короче Алины жгутика.

Переднеспинка по боковому краю резко сужена от основания к вершине, с более или менее прямым передним краем и широким кАиновидным выступом по заднему краю; перетяжка у переднего края явственная, заглазничные мопасти не выражены. Аорсальная поверхность в небольших выступающих зернах, в центре с крупным ромбовидным зерном, от которого к вершине и основанию тянется узкая неглубокая медиальная бороздка.

Надкрылья удлиненные, паралмельные, с хорошо выра женными плечами, с Ауговидным основным краем. В основной половине в крупных одиночных и сливающихся зернах, за серединой в рашпилевидных точках.

Щиток явственный.

Переднегрудь. Прекоксальные бугры переднегруди явственные.

Ноги. ПереАние голени по внутренней стороне с ши пами, 1-й и 2-й чменики мапок широкие, 2-й чменик немного больше 3-го, с полными губчатыми подошвами. Коготки у основания сросшиеся.

Вентриты в крупных голых точках (C. pigra) или без них (C. japonicas и C. neglectus).

Опушение с Аорсальной стороны из серых узких манцетовидных чешуек, формирующих на надкрыльях характерные 2 косые перевязи. Опушение Аорсальной и вентральной сторон из одинаковых чешуек (C. pigra) или чешуйки вентральной стороны значительно Алиннее (C. japonicas и C. neglectus).

Эндофамлус. Базальная область с крупным одновершинным базо-дорсальным выступом, возвышенным наА меАиальной областью, базо-Аорсальным бугром и сильно уА- линенными базо-вентральными бургами, прикрывающими мамелму пениса. Медиальная область круглая, с мощными, медио-латеральными (проксимальным и дистальным) и меАио-Аорсальными проксимальными буграми и медио-дорсальным выступом межАу ними. Апикальная область крупная, яйцевидная, с апикальными периаггоноподиальными буграми и уАлиненным аггоноподием.

Вентральная спикула. Аамемла уАлиненная, обратнояйцевиАная, ее Алина в 4 раза больше ширины, мировидная, без манубриума. Основание ветвей слегка утолщено, ветви ровные, у вершины с Аистальной уАлиненной Аопастью.

Сперматека. У C. pigra nodulus имеет Ава более или менее выраженных выступа, collum немного выступающий и узкий, но не конусовидный, ramus находится на конусовидном выросте nodulus, ramus и collum расположены на внешней стороне. Расстояние межАу ними в 4-5 раз больше продольного диаметра ramus. Cornu изогнут крючковидно, слабо сужен к вершине, на вершине закруглен. У C. japonicus и C. neglectus nodulus слабо выступает, collum широкий (C. japonicus), конусовидный, выдвинутый (C. neglectus), ramus у обоих видов широкий, cornu уАлиненный, крючковиАно изогнутый, с тупой вершиной.

ЯйцеклаА. Коксит короткий, конусовидный, на вершине с короткими хетами, стилус широкий, уАлиненный, его Алина в 2 раза больше ширины, на вершине закруглен и с пучком из коротких хет. У C. neglectus коксит менее конусовидно сужен к вершине, с почти парацмельными сторонами, пигментирован Ао середины и с небольшой мопастью на вершине внутреннего края.

Биология. Развивается на сложноцветных, главным образом, на видах подсемейства Lactucoideae триб Echinoneae, Carlineae, Cardueae (Cardinae, Centaureinae).

Распространение. Европа, Кавказ, Казахстан, Средняя Азия, Сибирь, Монголия, Китай, Япония, Северная Африка, Турция, Бангладеш. Завезен в Востосточную Канаду и на северо-восток США.

Изученный материах. Cleonis pigra (Scopoli, 1763), C. japonicus Faust, 1904 и C. neglectus Ter-Minassian et Egorov, 1981.

Xeradosomus gen. $\mathrm{n}$.

Рис. 50, 53-54, 59, 62, 68, 72-73, 77-78, 83-84, 89-90, 95 96

Типовой виА. Cleonus samsonovi Gebler, 1845.

Новый род вкцючает X. samsonovi (Gebler, 1845) comb. n., X. grigorievi Suvorov, 1915 comb. n.

Морфомогические замечания. Ранее виды нового рода вкцючались в род Adosomus на основании ряда внешних морфологических признаков (характерный пятнистый рисунок верха тела, вентриты с голыми неупорядоченными точками, мапки с губчатыми подошвами, широкий киль на Аорсальной стороне гомовотрубки, 1-й членик жгутика в 1.3-1.5 раза больше 2-го). ОАнако, как заметила еще Тер-Минасян [1988], род Adosomus не монолитный и вкАючает ряА виАов, не имеющих густых войлочных подошв, к тому же они имеют иное строение Аорсальной стороны головотрубки, а также слабо сросшиеся и широко расставленные коготки и несколько иное строение эндофациуса и терминалий самок. 


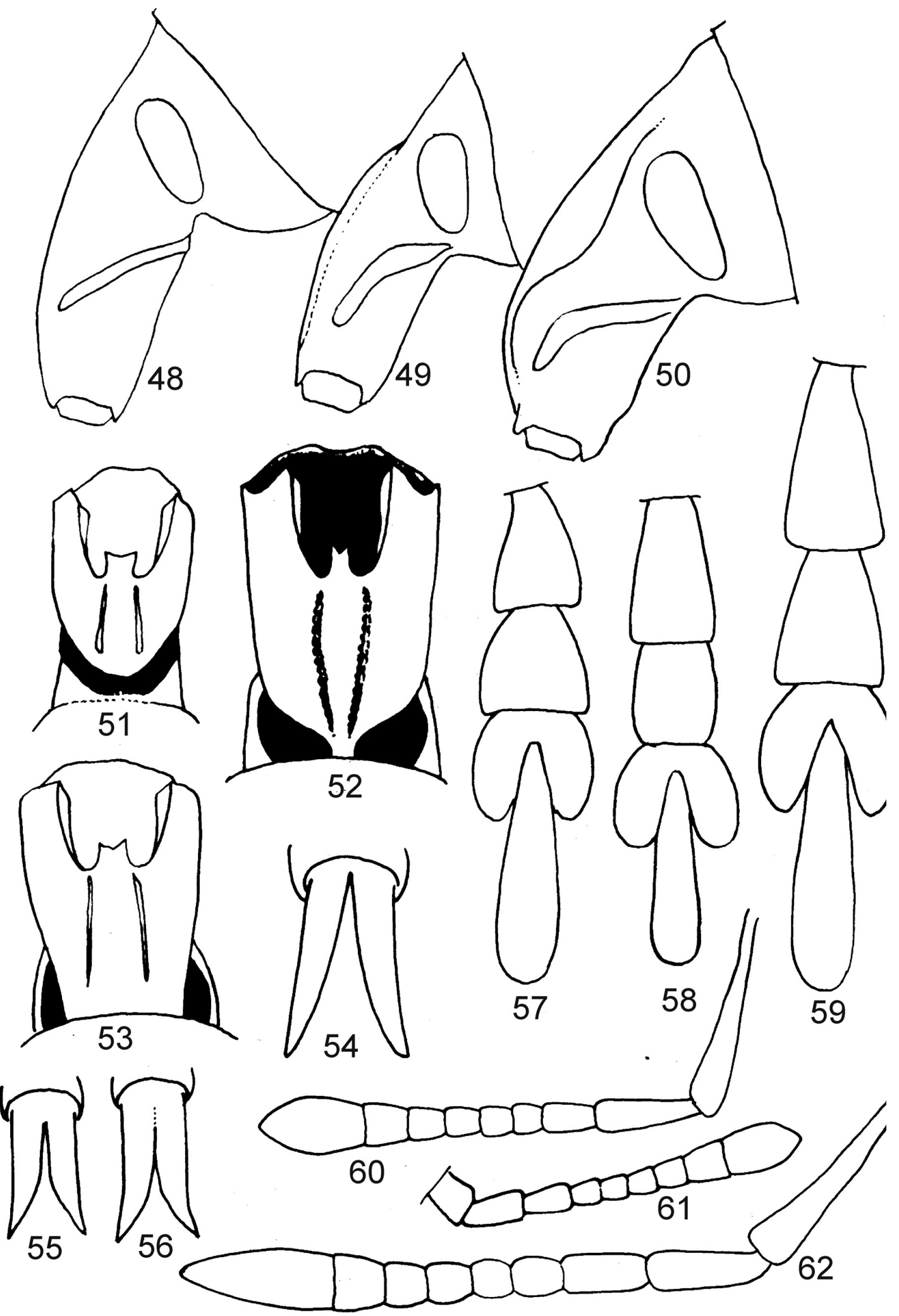

Рис. 48-62. Adosomus Faust и Xeradosomus gen. $\mathbf{n}$.

48-50 - Головотрубка (виА сбоку), 51-53 - головотрубка (вентральная сторона), 54-56 - коготки, 57-59 - мапка, 60-62 - усик. 48, 51, 55, 57, 60 A. roridus; 49, 52, 56, 58, 61 - A. granulosus; 50, 53-54, 59, $62-X$. samsonovi

Figs. 48-62. Adosomus Faust and Xeradosomus gen. n.

48-50 - Rostrum (side view), 51-53 - rostrum (ventral view), 54-56 - claws, 57-59 - tarsus, 60-62 - antenna. 48, 51, 55, 57, 60 - A. roridus; 49, 52, 56, 58, 61 - A. granulosus; 50, 53-54, 59, $62-X$. samsonovi. 
Описание. Головотрубка толстая, парацлельносторонняя, окаймменная кимями, ее дорсацьная сторона с широким слабо выступающим килем, разАвоенным у места прикрепления усиков, у основания с точкой. Медиальный киль с боков ограничен продольными понижениями ики глубокими проАольными ямками.

ПереАнеспинка равной Алины и ширины, передний край прямой, основной - слабо Ауговидный, боковые стороны от основания Ао передней трети прямые, Аалее к вершине постепенно сужены, преАвершинная перетяжка слабая Заглазничные мопасти слабо выступающие. Аорсальная поверхностьскрупнымизернамиицентральным ромбовидным зерном и продолженным впереА и назаА медиальными килем.

Надкрылья УАлиненно овацьные, почти парациельносторонние, их поверхность в многочисленных крупных и мекких зернах.

Щиток явственный, широкий, треугольный.

Опушение Аорсальной и вентральной сторон из эм^иптических и коротких манцетовидных чешуек.

Ноги. ПереАние голени с выемкой по внутренней стороне и с рядом коротких острых зубцов в ней. 2-й членик мапки более или менее уАлиненный, в 1.5 раза больше 3-го, равен или

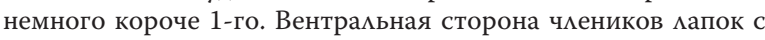
голой медиальной полоской. Коготки не сросшиеся.

Эндофациус с хорошо развитым уАлиненным одновершинным базо-дорсальным выступом, который у ряда виАов в средней части несет базо-дорсальные бугры. Базальный выступ Алинный, выАвинут более чем на половину своей Алины или немного короче. Базо-дорсальные бугры крупные, обычно налегают на мамемку пениса и охватывают ее. Медиацьная область крупная, круглая, с крупными, сикьно выступающими проксимальными Аорсальными буграми, межАу которыми находится короткий медио-дорсальный выступ. Аистальные бугры в меАиацьной области отсутствуют. МеАио-латеральные проксимальные бугры хорошо развиты, крыловидной формы; медио-латеральные дистальные бугры сливаются с меАиопроксимацьным бугром, образуя мощный крыловидный приАаток. МеАио-вентрахьный выступ крупный, серАцевиАной формы, несколько уступающий по размерам апикальной обмасти. Апикальная область крупная, с хорошо развитым апикальным скцеритным комплексом и примыкающими к нему апикальными буграми.

Вентральная спикула. Аамемла обратнояйцевидная, ее Алина в 1.6 раза больше ширины (в наибольшем месте), с широким Ауговидным основным краем, ветви ровные, Аистальные Аопасти широкояйцевидные, расставленные.

Сперматека. Nodulus с хорошо выраженными Авумя выступами, граница между которыми находится ближе к ramus Collum цихинарически выступающий, широкий (по крайней мере, шире ramus), находится на внешней стороне. Ramus yзкий, выступает коротким конусом. Расстояние межАу ramus и collum в 2 раза больше Аиаметра ramus. Cornu крючковиАный, с паралмельными сторонами, у самой вершины сужен в короткий «носик». Вершиная часть cornu направлена вАоль продольной оси nodulus.

ЯйцекмаА. Коксит короткий, конусовиАный, в апикаАьной части с Алинными одиночными щетинками, стилус короткий, ширина его в 2 раза меньше Алины, на вершине закруглен и в коротких хетах.

Биомогия. Все виды рода развиваются на полынях. X. grigorievi Suvorov, 1915 развивается на Artemisia santolinifolia Turcz. ex Besser. [Тер-Минасян, 1988].

$$
\text { Распространение. Южный Казахстан, }
$$

Туркменистан, Западная Сибирь, Китай, Монгомия.

Изученный материах. X. samsonovi (Gebler, 1845) и X. grigorievi Suvorov, 1915.
Adosomus Faust, 1904

Рис. 48-49, 51-52, 55-58, 60-61, 63-67, 69-71, 74-76, 79-82, 85-88, 91-94

Adosomus Faust, 1904: 188 (установмен в опреАелительной таблице).

Adosomus: Reitter, 1912: 46 (pro subgen. Cleonus).

Adosomus: Reitter, 1916: 83-84.

Adosomus: Voss, 1937: 258.

Adosomus: Тер-Минасян, 1988: 76.

=Stephanophorus Chevrolat, 1873: 39 (non Strikland, 1841) - синонимия установлена Alonzo-Zarazaga et Lyal, 1999.

Типовой вид. Curculio roridus Pallas, 1781 (по первоначальному обозначению).

Синонимические замечания. РoАStephanophorus, описанный Шевроля, явился преоккупированным названием Стрикланда [Strickland, 1841], что отмечено Заразагой [Alonzo-Zarazaga et Lyal, 1999]. Рейттер [Reitter, 1912] приводит Adosomus и вместе с ним Cyphocleonus как подроды Cleonus благодаря наличию у них хорошо выраженных зерен на переАнеспинке и на основании надкрылий.

Таксономические замечания. У Фауста [Faust, 1904] род Adosomus по особенностям строения задней мапки входит в оАну группу с Cleonus, Cyphocleonus и Lixomorphus и хорошо отАелен от близких родов Xanthochelus и Pleurocleonus. Рейттер [Reitter, 1912] в ранней работе придерживался самостоятельности родов, а в Аальнейшем [Reitter, 1916] объединил Adosomus, Cleonus и Cyphocleonus в один роА, игнорируя отсутствие медиальной бороздки головотрубки у Adosomus и Cyphocleonus, считая этот признак второстепенным. Тер-Минасян [1988] придерживалась самостоятельности этих довольно близких родов.

Морфологические замечания. ААя всех видов характерны короткие и острые зубцы на внутренней стороне передних голеней. Этот признак присутствует также у Xenomacrus glacialis Herbst, 1797 и у некоторых Cyphocleonus (C. dealbatus Gmelin, 1790, C. trisulcatus Herbst, 1795). Головотрубка с вентральной стороны отделена от головы заметным поперечным угцублением.

Описание. Головотрубка толстая, паралмельносторонняя, медиальный киль слабо выступает, сглаженный, еАва заметный, не ограничен по сторонам боковыми кимями. Вентральная сторона головотрубки в крупных точках и с Авумя тонкими медиацьными продольными борозАками, огражАающими субментум. Усиковые борозАки у основания головотрубки по вентрацьной стороне соеАинены (A. roridus) ими отАелены Аруг от Аруга, не ограничивая субментум от головной капсулы (A. granulosus). Эпистом плоский, уАлиненно треугольный, ограничен по сторонам более или менее углубленными борозАками, с выемкой по переАнему краю (A. roridus) или без нее (A. granulosus).

Аоб слабо вАавленный или прямой.

Прементум с прямым (A. roridus) или слабо Ауговидно вогнутым переАним краем (A. granulosus), с боков равномерно сужен к переднему и заднему краям (A. granulosus) или сицьнее сужен у переднего края (A.roridus); у основания с более ими менее явственной выемкой по боковому краю и Ауго- 


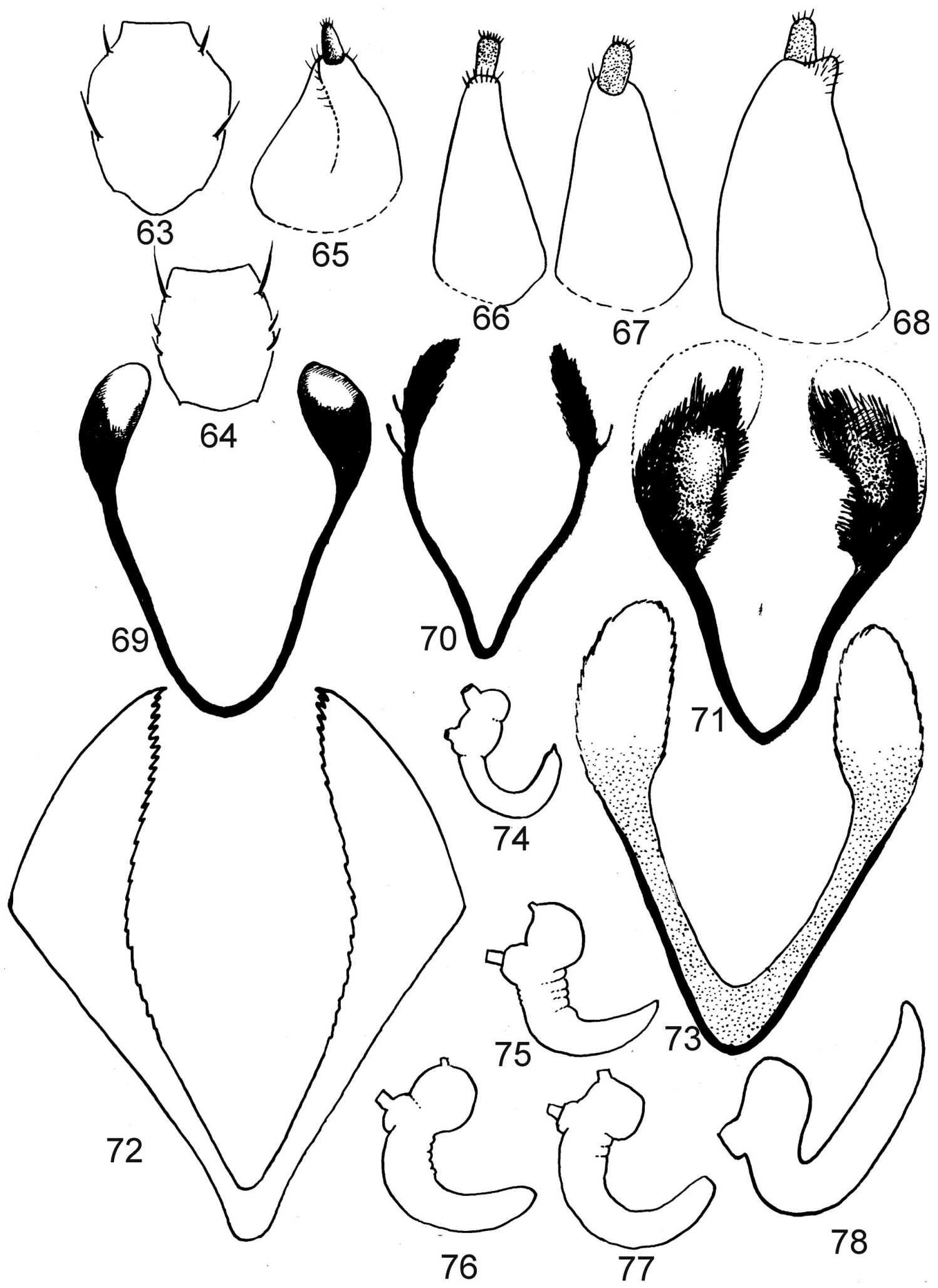

Рис. 63-78. Adosomus Faust и Xeradosomus gen. n.

63-64 - прементум, 65-68 - яйцекмад; 69-73 - вентрацьная спикула, 74-78 - сперматека. 63, 65, 69, 74 - A. roridus; 64, 66 - A. granulosus; 67, 71, 76 - A. parallelocollis; 70, 75 - A. melogrammus; 68, 72, 77 - X. samsonovi; 73, 78 - X. grigorievi.

Figs. 63-78. Adosomus Faust and Xeradosomus gen. n.

63-64 - prementum, 65-68 - coxite and stylus; 69-73 - speculum ventrale, 74-78 - spermatheca. 63, 65, 69, 74 - A. roridus; 64, 66 - A. granulosus; 67, 71, 76 - A. parallelocollis; 70, 75 - A. melogrammus; 68, 72, 77 - X. samsonovi; 73, 78 - X. grigorievi. 

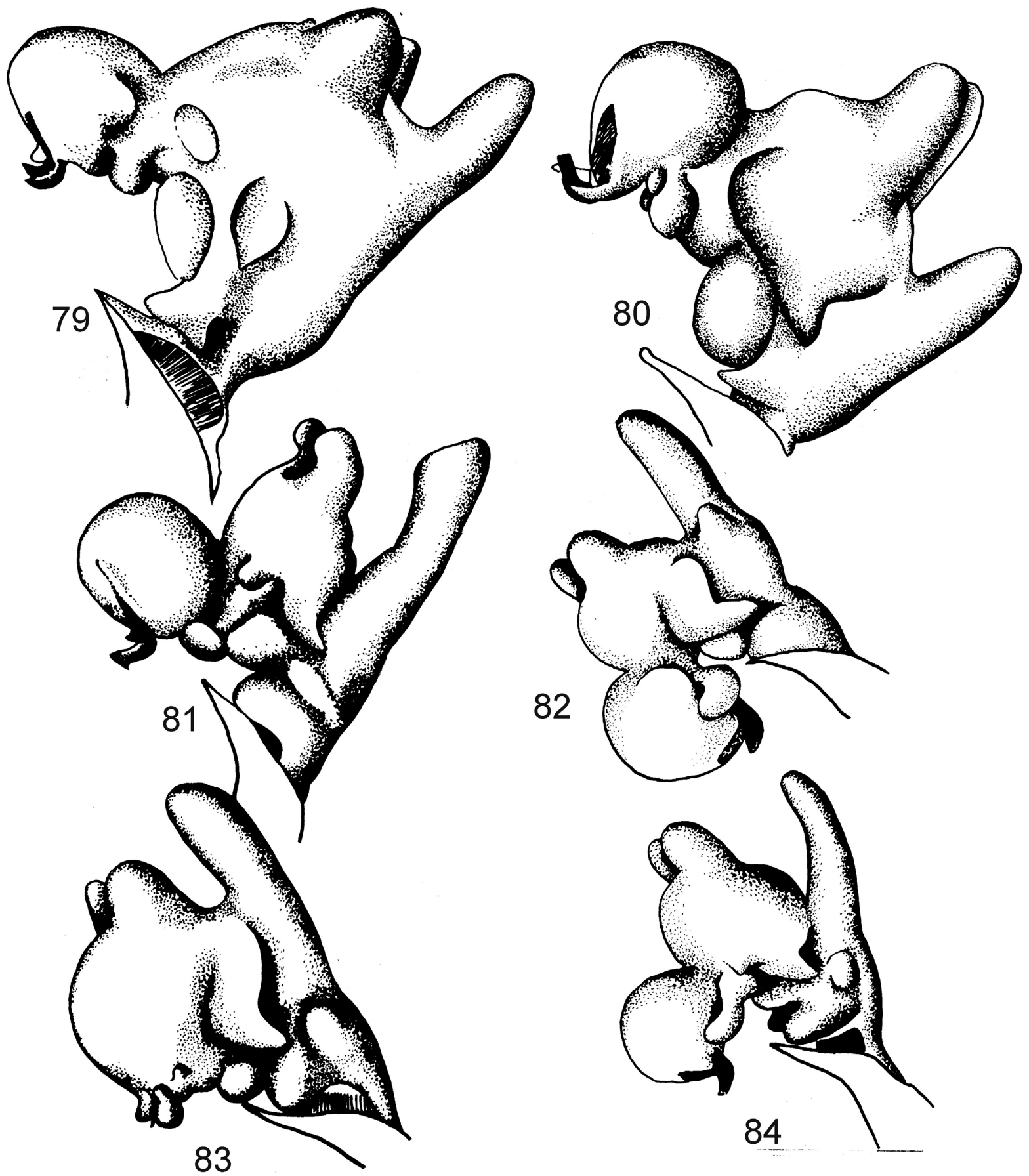

Рис. 79-84. Adosomus Faust и Xeradosomus gen. n. (эндофамлус, вид сбоку)

79 - A. roridus; 80 - A. granulosus; 81 - A. parallelocollis; 82 - A. melogrammus; 83 - X. samsonovi; 84 - X. grigorievi.

Figs. 79-84. Adosomus Faust and Xeradosomus gen. n. (internal sac, side view)

79 - A. roridus; 80 - A. granulosus; 81 - A. parallelocollis; 82 - A. melogrammus; 83 - X. samsonovi; 84 - X. grigorievi.

виАным выступом в основании. С каждой стороны с 3-мя $(A$ granulosus) ими 2-мя хетами.

Постментум маленький, узкий, не стебельчатый, Алина его в 3 раза меньше Алины ротовой выемки, с острым треугольным вырезом по переднему краю.

Максимла с более или менее уАлиненной галеомациниацьной мопастью, с 5-ю крупными равными (A. roridus) или неравными крючковидными мациниальными зубцами: 3 узких и 4 крупных широких (A. granulosus); галеальный ряд из 3-х коротких шиповидных зубцов, значительно уступающих по Алине мациниальным. Вершина и наружная сторона галео-лациниальной мопасти в Алинных и тонких щетинках, равных или немного уступающих Алине мациниальным зубцам. Пальпигер равен Алине 1-го и 2-го чмеников щупика, с Алинными щетинками по внешней стороне, 1-й и 2-й чкеники щупика кваАратные, 3-й - узкий, немного короче 2-го.

Усики. 1-й членик жгутика в 2 раза больше 2-го ( $A$. roridus) ими немного больше 2-го (A. melanogrammus и $A$. parallelicollis).

ГАаза овальные, зауженные книзу, плоские (A. roridus) ими слабо выступают за контуры головы (A. granulosus, $A$. melanogrammus, A. parallelocollis). 
Переднеспинка слабо поперечная, передний край прямой, основной - слабо кАиновиАно выАвинут, боковые стороны от основания Ао преАвершинной перетяжки АуговиАно сужены. ПреАвершинная перетяжка глубокая, хорошо видна сверху. Заглазничные мопасти слабые. Аорсальная поверхность в крупных зернах, меАиальный кимь широкий плоский или отсутствует.

Надкрылья паралмельные или слабо, но явственно расширены во второй половине.

Щиток треугольный, хорошо виАен сверху или несколько утоплен своим основанием (A. roridus).

Ноги. Голени с шипами по внутреннему краю на всех ногах ики Аишь на переАних, мапки широкие, их нижняя сторона с полной войлочной подошвой. Коготки от основания сросшиеся Ао середины.

Опушение верха тела из удииненно-ланцетовидных чешуек.

Эндофамлус. Все виды характеризуются хорошо развитым УАлиненным оАновершинным базо-дорсальным выступом, который у ряда видов (A. melogrammus и A. parallelocollis) в среАней части несет базо-дорсальные бугры. Эти бугры отсутствуют у A. granulosus и A. roridus. Базальный выступ Аовольно Алинный (A. melogrammиs и A. parallelocollis), выдвинут более чем на половину своей длины или немного короче. БазоАорсальные бугры крупные, обычно налегают на мамемку пениса или Ааже охватывают его. Медиацьная область крупная, круглая, с крупными, сильно выступающими проксимальными Аорсальными буграми, межАу которыми находится короткий медио-дорсальный выступ. Аистальные бугры в медиальной области отсутствуют. Медио-латеральные проксимальные бугры хорошо развиты, крыловидной формы; медио-латеральные дистальные бугры имеются у A. parallelocollis, A. roridus и A. melogrammus, они сливаются с медио-проксимацьным бугром, образуя мощный крыловидный придаток. МеАио-вентральный выступ крупный, серАцевиАной формы, несколько уступающий по размерам апикальной области, хорошо развит у всех видов. Апикальная область крупная, с хорошо развитым апикацьным скмеритным комплексом и примыкающими к нему апикацьными буграми.

Вентральная спикула. Аамемла обратнояйцевидная, ее Алина в 1.6 раза больше ширины (в наибольшем месте), с широко Ауговидным основным краем, ветви ровные, Аистальные Аопасти широкояйцевидные, расставленные.

Сперматека. Nodulus с хорошо выраженными 2-мя выступами, граница межАу которыми находится ближе к ramus. Collum цикинарически выступающий, широкий (по крайней мере, шире ramus). Ramus конусовидный, узкий. Расстояние межау ramus и collum в 2 раза больше Аиаметра ramus. Cornu крючковидный, с парамлемьными сторонами, у самой вершины сужен в короткий «носик». Вершинная часть cornu направ-

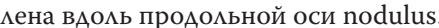

ЯйцеклаА. Коксит короткий, конусовидный, в апикамьной части с Алинными оАиночными щетинками, стилус короткий, ширина его в 2 раза меньше Алины, на вершине закруглең и в коротких хетах.

Биомогия. Развиваются на полынях

Распространение. Юго-Восточная Европа, Кавказ, Казахстан, Кыргызстан, Сибирь, Иран, Монголия, Китай, Корея, Япония.

Изученный материах. A. granulosus (Mannerheim, 1825), A. melonogrammus (Motschulsky, 1854), A. roridus (Pallas, 1781) и A. parallelocollis Heller, 1923. Остались неизученными A. albisquama Ter-Minassian, 1976, A. karelini (Fahraeus, 1842) и A. koreanus Voss, 1937.
Adosomus (Adosomus) Faust, 1904

Рис. 48, 51, 55, 57, 60, 63, 65, 69, 74, 79

Номинативный подрод вкмючает мишь 1 виА - $A$. roridus Pall.

Описание. Усиковые бороздки у основания головотрубки с вентральной стороны соединены, ограничивая головотрубку от головной капсулы широкой и глубокой борозАкой. Эпистом бомее ими менее явственный. Аорсальная сторона головотрубки без вдавления переА медиальным килем. Прементум с 2-мя хетами по боковому краю. Максилма, с 5-ю крупными равными крючковидными

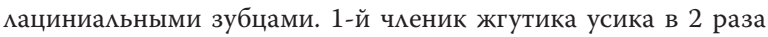
больше 2-го. Глаза плоские, не выходят за контуры головы. НаАкрылья паралмельные. Основание щитка утопцено и скрыто наАкрыльями. Зубцы по внутренней стороне голеней развиты Аишь на передних ногах.

Распространение. Южная Европа, юг и юговосток европейской части России.

Adosomus (Pseudoadosomus) subgen. n.

Рис. 49, 52, 56, 58, 61, 64, 66-67, 70-71, 75-76, 80-82 1825

Типовой виА. Cleonus granulosus Mannerheim,

Новый подроА вкмючает виАы Аальневосточной фауны A. granulosus, A. melogrammus, A. parallelocollis.

Описание. Усиковые бороздки у основания головотрубки по вентрацьной стороне не соединены. Эпистом не выражен. Аорсальная сторона головотрубки с явственным вАавлением переА мбом, с широким плоским меАиальным килем или возвышенной поверхностью, ограниченной по сторонам широкими продольными вдавлениями. Прементум с 3-мя хетами по боковому краю. Максимла с неравными крючковиАными мациниальными зубцами: 3 узких и 4 крупных широких. 1-й членик жгутика усиков немного больше 2-го. ГАаза слабо выпуклые. Надкрылья слабо расширены во второй половине. Щиток явственный, треугольный, хорошо виден сверху. Зубцы по внутренней стороне голеней крупные, развиты на всех ногах.

Распространение. Восточная Сибирь, Забайкалье, Аамьний Восток, Северный Китай, Корея, Япония.

Биология. Развиваются на полынях.

\section{ОПРЕАЕАИТЕАЬНАЯ ТАБАИЦА РОАОВ XERADOSOMUS GEN. N. И ADOSOMUS FAUST}

1 (2) 2-й чменик заАней мапки уАлиненный, в 1.52 раза больше 3-го. Аапки с вентральной стороны с редументами войлочных подошв. ПереАнеспинка УААиненная, с тонким меАиальным килем, иногда утолщенным в среАней чести. Верх тела в широких $а н-$ цетовидных чешуйках и многочисленных овацьных зернах ...................................Хeradosomus gen. n.

2 (1) 2-й чменик задней мапки не уАлинен, вентральная поверхность мапки с полной войлочной поАошвой Adosomus

3 (4) Основной край переднеспинки со слабым выступом в центре. Надкрымья с более ими менее паралмельными сторонами. Усиковые борозАки с вентральной стороны у основания головотрубки соеАинены. 


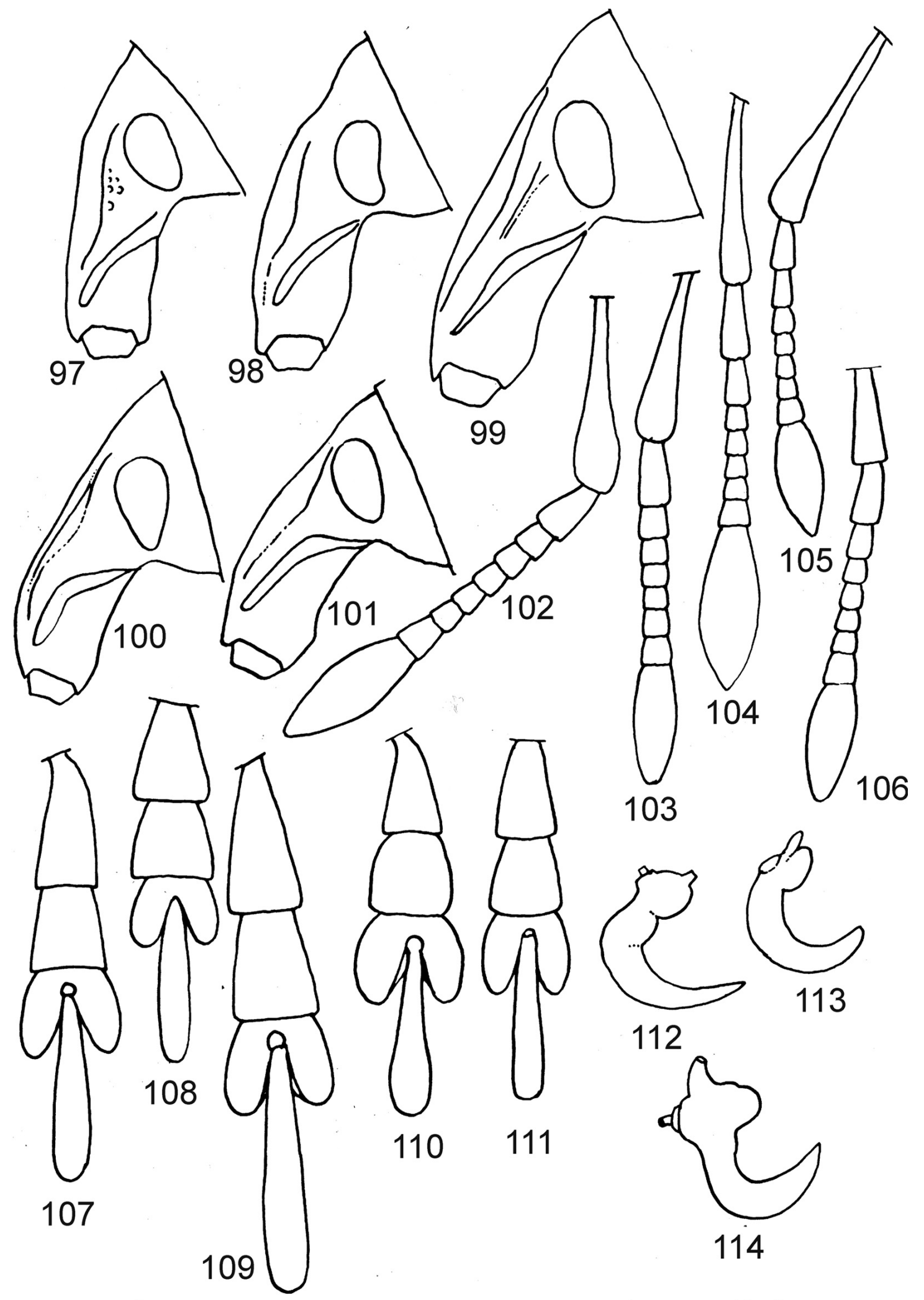

Рис. 97-114. Cyphocleonus Motschulsky

97-101 - головотрубка, вил сверху, 102-106 - усик, 107-111 - задняя мапка, 112-114 - сперматека. 97, 102, 107, 114 - C. achates; 98 , 103, 108 - C. cenchrus; 99, 104, 109 - C. morbillosus; 100, 105, 110, 113 - C. trisulcatus; 101, 106, 111, 112 - C. dealbatus.

Figs. 97-114. Cyphocleonus Motschulsky

97-101 - rostrum, from above, 102-106 - antenna, 107-111 - metatarsus, 112-114 - spermatheca. 97, 102, 107, 114 - C. achates; 98, 103, 108 - C. cenchrus; 99, 104, 109 - C. morbillosus; 100, 105, 110, 113 - C. trisulcatus; 101, 106, 111, 112 - C. dealbatus. 


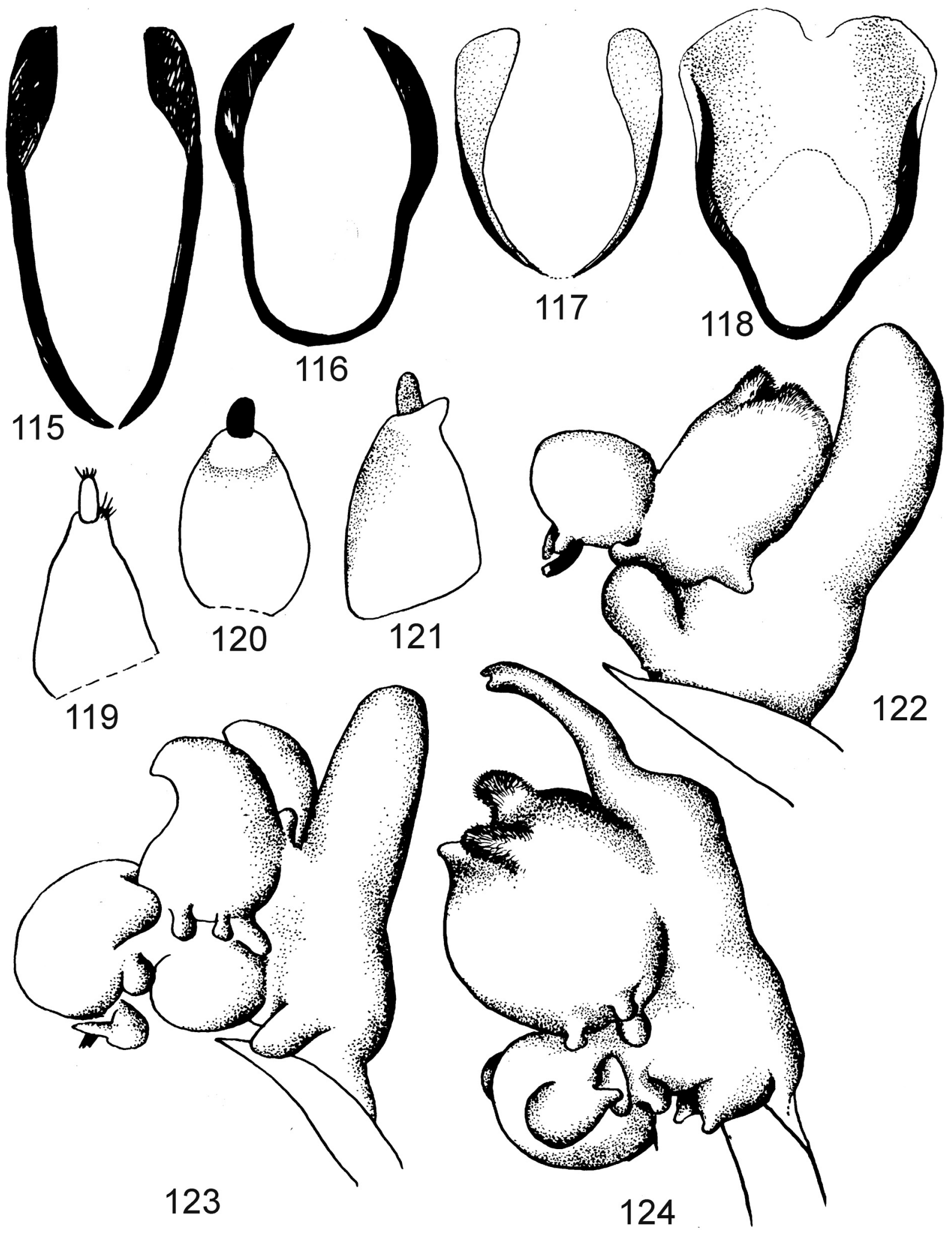

Рис. 115-124. Cyphocleonus Motschulsky

115-118 - вентральная спикула, 119-121 - яйцекмаА, 122-124 - эндофалмус, вид сбоку.

115, 120, 122 - C. achates; 123 - C. cenchrus; 118, 121 - C. morbillosus; 116, 124 - C. trisulcatus; 117, 119 - C. dealbatus. Figs. 115-124. Cyphocleonus Motschulsky

115-118 - speculum ventrale, 119-121 - coxite and stylus, 122-124 - internal sac, side view.

115, 120, 122 - C. achates; 123 - C. cenchrus; 118, 121 - C. morbillosus; 116,124 - C. trisulcatus; 117, 119 - C. dealbatus. 
Аоб пноский. Adosomus (s. str.)

4 (3) Основной край переАнеспинки прямой, надкрылья с наибольшей шириной за серединой. Усиковые борозАки с вентральной стороны у осно-

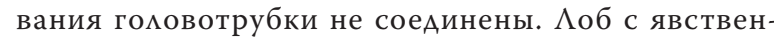
ным вАавлением перед глазами. ..Adosomus (Pseudoadosomus) subgen. n.

\section{Cyphocleonus Motschulsky, 1860}

Рис. 97-130

Cyphocleonus Motschulsky, 1860: 540.

Cyphocleonus: Reitter, 1916: 84 (pro subgen. Cleonus)

$$
\text { Cyphocleonus: Тер-Минасян, 1988: } 81 .
$$

Типовой виА. Curculio cenchrus Pallas, 1781.

Таксономические замечания. РоА Cyphocleonus описан Мочульским в определительной таблице и рассматривается в непосреАственной близости к Porocleonus и Oosomus (=Pseudocleonus). У Шевроля [Chevrolat, 1873] он близок к Mecaspis и Pseudocleonus. Фауст [Faust, 1904] рассматривает Cyphocleonus в ближайшем соседстве с Adosomus, Cleonus и Brachycleonus. Рейттер [Reitter, 1916] по наличию голых зерен на Аиске переднеспинки и надкрыльях рассматривал Cyphocleonus как подрод Cleonus. Все последующие авторы придерживались самостоятельности рода.

Описание. Головотрубка со срединным килем и явственными боковыми килями, ее нижняя сторона с глубоким продольным медиальным вАавлением, ограниченным с боков выступающими валиками. Усиковые бороздки на нижней стороне головотрубки не соединяются. Эпистом слабый, по бокам в основании с пучками щетинок.

Прементум с широкой выемкой по переднему краю, слабо уАлиненный, бока округлые с 2-мя боковыми хетами, основание с Ауговидным выступом. Постментум поперечный, слабо стебельчатый, со слабой выемкой по переднему краю.

Максилма широкая. Аациниальный ряд из зубцов двух типов: 3-4 узких шиловидных на вершине и 4 крупных острых крючковидных по внешнему краю. Галеальный ряд из скопления 5-6 коротких шиповидных зубцов, не сложенных в стройный ряд. Пальпигер уАлиненный, у вершинного угла и по внешней стороне с пучком Алинных щетинок. 1-й и 2-й чменики щупика УАлиненные (в 1.5 раза больше ширины), в 2 раза уже пальпигера, 3-й также уАлиненный (в 2 раза больше ширины) с заостренной вершиной, немного уже 2-го.

Усики. 1-й членик жгутика усика в 1.5 раза больше 2-го, 2-й - немного больше 3-го, 3-6-й - почти равные, булава уАлиненно веретеновидная или удлиненно овальная.

ГАаза овальные или уАлиненно-овальные, плоские или слабо выпукмые.

Переднеспинка еАва Алиннее своей ширины. Аиск переднеспинки с зернами, медиальный киль тонкий, сглаженный или кимя нет (C. cenchrus), заглазничных мопастей нет, задний край переднеспинки с выступом. Надкрылья уАлиненные, паралмельносторонние, по всей поверхности в зернах.

Опушение верха тела из манцетовидных чешуек.

Ноги. Передние голени по внутренней стороне с короткими острыми зубчиками или без них. Членики задних мапок не УАлинены, с войлочными подошвами. Коготки сросшиеся.

Вентриты покрыты явственными ики неотчетливыми голыми пятнами или без них.

Эндофалцус. Строение эндофалцуса позволяет разбить род на Аве группы. В первую группу входят C. dealbatus и $C$. trisulcatus, во вторую - C. cenchrus, C. achates. Аیя первой группы характерно сильное развитие в базальной области базо-дорсального выступа, причем у исследованных видов он сильно выдвинут наА медиальной областью и на вершине разАвоен. Базо-Аорсальный бугор более или менее крупный, базовентральный бугор симьно увеличен, прикрывает мамемлу пениса. Медиальная область выпукмая, шаровидная, с Авумя крупными выступающими медио-Аорсальными проксимальными буграми и небольшим медио-Аорсальным выступом межАу ними. Медио-дорсальные дистальные бугры отсутствуют. Медио-цатеральные (проксимальный и вентральный) бугры более или менее развиты, выступающие. Медио-вентральный выступ небольшой, слабо дифференцирован. Апикальная область мощная, яйцевидная, резко отАелена от медиальной области и имеет сильно увеличенные апикальные (проксимальные и дистальные) бугры. Периаггоноподиальных бугров нет, аггонопорий слабо выступает. У второй группы базо-Аорсальный выступ крупный, мощный, оАновершинный, сильно выступает наА медиальной областью, базо-Аорсального бугра нет, базо-вентральный бугор небольшой. Медиальная область крупная, с сильно развитыми медио-дорсальными дистальными буграми и медио-Аорсальным выступом межАу ними. Имеются также слабые медио-латеральные (проксимальный и Аистальный) бугры и сильно выступающий поперечный, подушковидный медио-вентральный выступ. Апикальная обмасть небольшая, по сравнению с виАами первой группы, кругмая и не так резко отделена от медиальной области. Она не несет бугры, кроме периаггоноподиальных, и имеет крупный, направменный впереА аггонопорий.

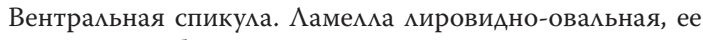

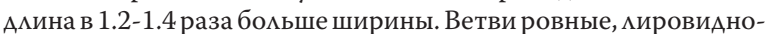
изогнутые с манцетовидными Аистальными мопастями. Место соединения ветвей не обособлено.

Сперматека.Аля рода в целом характерен болееили менее сильно выдвинутый nodulus по внутренней стороне (наиболее выдвинут среди изученных видов у $C$. achates). Ramus у всех изученных виАов отходит поА прямым углом к collum. Collum короткий, конусовидный, cornu - крючковиАный, у основания почти прямой, Аалее к вершине более или менее изогнутый. y C. trisulcatus вершина cornu закруглена. Расстояние межАу ramus и collum равно половине ширины ramus.

Яйцекмад. Коксит широкий, обратнояйцевидный или конусовидный, стикус короткий широкий, более или менее пигментирован (C. cenchrus и $C$. achates), или коксит конусовидный, а стихус узкий, не пигментирован ( $C$. dealbatus).

Распространение. Европа, Кавказ, Казахстан, СреАняя Азия, Монголия, Китай, Сибирь, Иран, Ирак, Турция, Сирия, Израиль, Аєжир, Марокко, Египет, Канарские острова, Сенегац.

Биология. Виды рода развиваются на корнях сложноцветных (Carduus, Cirsium, Onopordon acanthium, Achillea mollis, Artemisia, Achillea, Matricaria, Centaurea, Chrysanthemum и Ар.)

Изученный материал. Cyphocleonus trisulcatus (Herbst, 1795), C. cenchrus (Pallas, 1781), C. dealbatus (Gmelin, 1790), C. achates (Fahraeus, 1842), C. morbillosus (Fabricius, 1792) и C. adumbratus (Gebler, 1830). Остался неизученным C. immemoratus Ter-Minassian, 1962.

Строение медиальной области эндофамлуса позволяет разбить род на Ава подрода. ОАин, близкий по строению эндофамхуса к роду Cleonis, имеет крупную возвышенную поверхность, сформированную за счет объединения бугров медиальной области, и с одно- 


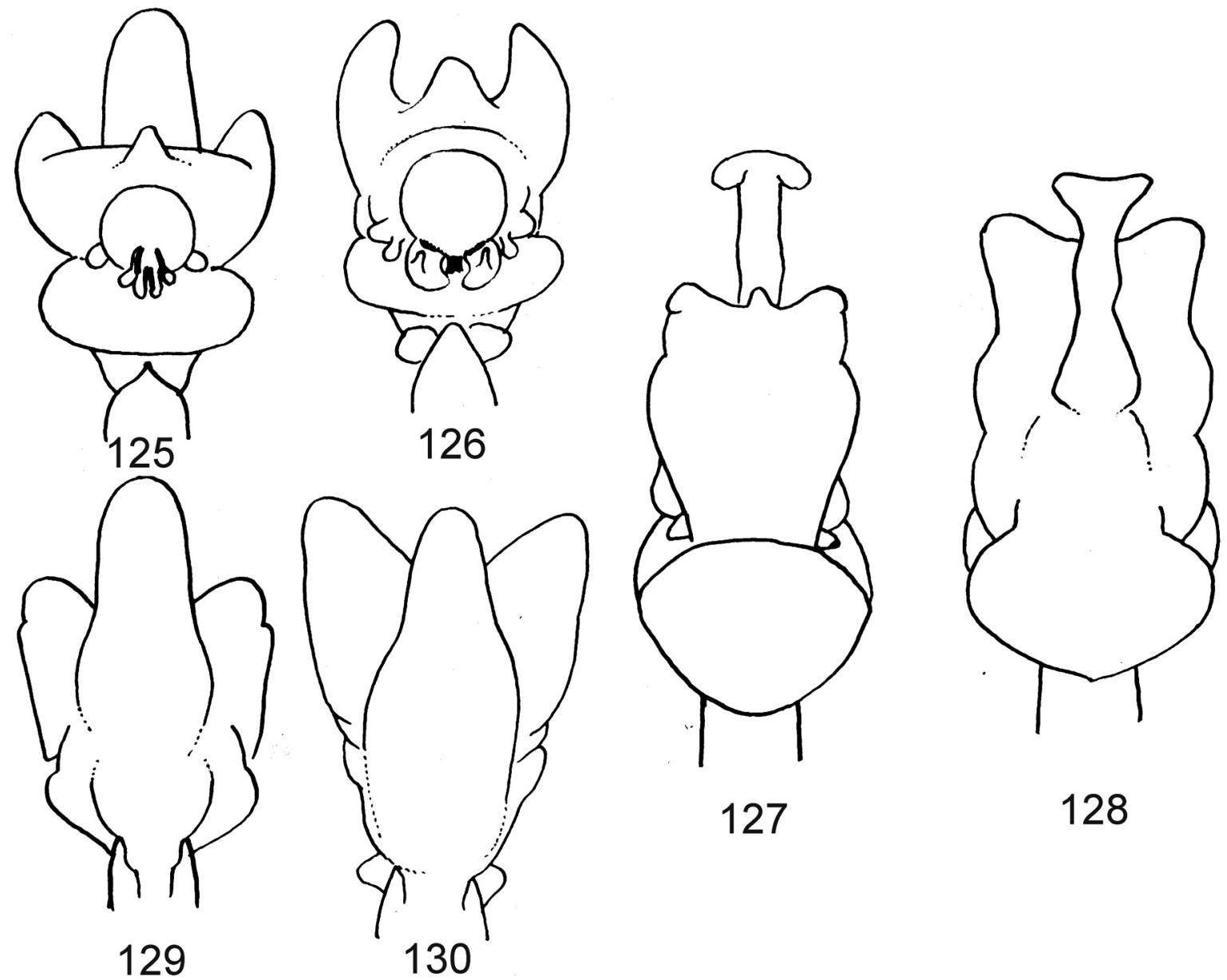

Рис. 125-130. Cyphocleonus Motschulsky

125-128 - эндофамлус, вид спереди, 128-130 - эндофамлус, вид сзади. 125, 128 - C. achates; 126, 129 - C. cenchrus; 127,130 - C. trisulcatus.

Figs. 125-130. Cyphocleonus Motschulsky

125-128 - internal sac, ventral view, 128-130 - internal sac, dorsal view. 125, 128 - C. achates; 126, 129 - C. cenchrus; 127,130 - C. trisulcatus

вершинным базо-дорсацьным выступом, и рассматривается нами как номинативный. Аругой, имеющий в меАиацьной области большое число изолированных бугров и с Алинным узким раздвоенным на вершине базо-дорсальным выступом описан как новый: Neocyphocleonus subgen. $\mathrm{n}$.

Cyphocleonus (Cyphocleonus) Motschulsky, 1860 Рис. 97-99, 102-104, 107-109, 114-115, 118, 120, 122-123, 125-126, 128-129

Номинативный подроА вкмючает 2 вида: C. cenchrus и C. achates.

Описание. Аорсальная сторона переднеспинки без медиального кимя. Глаза овацьные, слабо заужены снизу, более или менее выпукмые. Булава усиков уАлиненная, 1-й чиеник жгутика усика в 1.3-1.5 раза больше 2-го, 7-й - с равной Алиной и шириной. Сперматека с сильно выступающим nodulus, изогнутым в сереАине cornu и конусовидным collum. Ветви и дистальные мамелмы вентрацьной спикулы хорошо скмеротизованные. ЯйцекмаА овацьный, с более ими менее широким пигментированным стилусом. Эндофалиус с мощным базо-дорсальным выступом, более ими менее крупной медиальной областью, апикальная область значительно меньше, с хорошо развитыми крупными аггоноподиальными буграми.

Распространение. Юг и юго-восток европейской части России, Кавказ, Казахстан, Туркменистан, Узбекистан, Иран.

Биомогия. Развиваются на васильках (Centaurea spp.).

Cyphocleonus (Neocyphocleonus) subgen. n. Рис. 100-101, 105-106, 110-113, 116-117, 119, 124, 127, 130

Типовой виА. Curculio dealbatus Gmelin, 1790.

К новому подроду относятся C. dealbatus, $C$. trisulcatus, C. adumbratus.

Описание. Кимь головотрубки широкий, разделен в переАней половине, равен ширине ровных, не углубленных в среАней части боковых бороздок; боковые канты головотрубки явственные, заканчиваются наА глазами. Гцаза овацьные, более ими менее явственно заужены книзу и плоские. Була- 
ва усиков коротко овацьная, 1-й чменик жгутика в 1.5-2 раза больше 2-го, 7-й чменик - поперечный. Сперматека со слабо выступающим nodulus, cornu изогнут от основания, collum не конусовидный. Ветви вентральной спикулы слабо скмеротированные, тонкие, широко расходящиеся, у C. dealbatus ветви в узле не сросшиеся. ЯйцеклаА конусовидный, с тонким, уАлиненным, не скмеротизованным стикусом. Эндофахиус с крупным, тонким на вершине и разАвоенным базо-дорсацьным выступом, медиальная область крупная, с многочисленными Аополнительными буграми, апикальная область также крупная.

Распространение. Средняя и Южная Европа, Кавказ, Казахстан, Кыргызтан, Северо-Западный Китай, Иран.

Биология. Развиваются на сложноцветных (Artemisia, Achillea, Centaurea, Carduus, Arctium, Onopordon, Circium и Aр.).

\section{ОПРЕАЕАИТЕАЬНАЯ ТАБАИЦА ПОАРОАОВ CYPHOCLEONUS MOTSCHULSKY}

1 (2) ГАаза плоские. Булава усиков коротко овальная, 1-й чменик жгутика в 1.5-2 раза больше 2-го, 7-й чменик - поперечный. Кимь головотрубки широкий, разделен в передней половине, равен ширине ровных, не угкубленных в средней части боковых бороздок; боковые канты головотрубки явственные, заканчиваются наА глазами. ПереАние голени по внутренней стороне с короткими острыми зубчиками. Эндофам ус с раздвоенным базо-дорсальным выступо

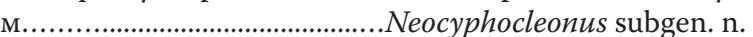

2 (1) Глаза более или менее выпукмые. Булава усиков уАлиненная, 1-й членик жгутика усика в 1.3-1.5 раза больше 2-го, 7-й - с равной Алиной и шириной. Передние голени на внутренней стороне без коротких острых зубчиков. Эндофамлус с одновершинным базоАорсальным выступ. Cyphocleonus

\section{Бмагодарности}

Аанная работа выполнена на богатейших материалахкомлекцииLixinae3оологическогоинститута РАН (Санкт-Петербург), которые были предоставмены автору благодаря кюбезности Б.А. Коротяева и Г.Э. Аавидьяна, без Аружеского участия которых настоящая работа никогда бы не была завершена. Большой подАержкой в работе по изучению генитального аппарата и особенно эндофамлуса долгоносиков мы обязаны Г.С. МеАведеву. Не могу обойти вниманием и моего первого наставника в изучении Аолгоносиков,
M.Е. Тер-Минасян, много саелавшей в изучении Lixinae Палеарктики и оказавшей большую поААержку на моих первых этапах работы. Хочу поблагодарить и моих ближайших ростовских комлег, принявших участие в обсужАении результатов настоящей работы и внесших ряд ценных замечаний.

\section{Митература}

Арзанов Ю. Г. 2003. Использование признаков внутреннего мешка эдеагуса в систематике Аолгоносикообразных жуков (Coleoptera, Curculionidae) // Энтомол. обозр. Том 82. Вып. 3. С. 701-719.

Арзанов Ю. Г. 2004. Обзор палеарктических Аолгоносиков трибы Cleonini (Coleoptera: Curculionidae, Lixinae), обитающих на сложноцветных // Труды государственного природного заповедника «Ростовский». Вып. 3. С. 209-226.

Арнольди А.В. 1956. Новые долгоносики (Coleoptera, Curculionidae) из СреАней Азии // Энтомол. обозр. Том 35. Вып. 3. С. 680-692.

Тер-Минасян М. Е. 1988. Жуки-Аолгоносики подсемейства Cleoninae фауны СССР. Корневые долгоносики (Триба Cleonini). $\Lambda .:$ Наука. $233 \mathrm{c}$.

Alonso-Zarazaga M. A., Lyal Ch. H. C. A. 1999. World catalogue of families and genera of Curculionoidea (Insecta: Coleoptera). Madrid. 315 p.

Bedel L. 1909. Catalogue des Cleoniens (Coleoptera, Curculionidae) de l'Ègypte et du Haut-Nil // Bulletin de la Société Entomologique d'Egypte. Vol. 2. P. 89-107.

Chevrolat L. A. A. 1873. Mémoire sur les Cléonides // Mémoire de la Société Royale des Sciences de Liége. Vol. 5. No 6. P. 1-118.

Dejean P. F. M. A. 1821. Catalogus de la collection de Coléoptères de M. le Baron Dejean. Paris, Crevot. 8. 136 pp.

Dieckmann L. 1983. Beitrage zur Insektenfauna der DDR: Coleoptera Curculionidae (Tanymecinae, Leptopiinae, Cleoninae, Tanyrhynchinae, Cossoninae, Raymondionyminae, Bagoinae, Tanysphyrinae) // Beitr.Ent..Berlin, T. 33. No 2. S. 257-381.

Faust J. 1904. Revision der Gruppe Cléonides vrais // Deutsche entomol. Zeitschrift. T. 1. S. 177-284.

Gistel J. 1856. Die Mysterien der europäischen Insectenwelt. Kempten, Dannheimer. T. 12.532 pp.

Hustache A. 1929. Curculionidae // Voyage de Ch. Alluaud et R. Jeannel en Afrique Orientale (1911-1912). Rèsultats scentifiques, Coleoptera. T. 30. P. $365-562$.

Motschulsky V. 1860. Coléoptéres rapportés en 1859 par M. Sévertsef des Steppes méridionales des Kirghises, et enumerés par V. de Motschulsky // Bulletin Physico-Mathématique de l'Academie Impériale des Sciences de St. Petersburb. T. 2. No 8. P. 513-544.

Reitter E. 1912. Bestimmungs-Schlüssel der mir bekamnten europäschen Gattungen der Curculionidae, mit Einschluss der mir bekannten Gattungen aus dem palaearctischen Gebiete // Verhandlungen des naturforschenden Vereines in Brünn. T. 51. P. 1-90.

Reitter E. 1916. Fauna Germanica. Die Käfer des Deutschen Reiches. Nach der analytischen Methode bearbeitet. Stuttgart. T. 5. 343 pp.

Rye E.C. 1875. Insecta. Coleoptera // The Zoological Record of 1873. London. P. 248-342.

Schoenherr C. J. 1823. Curculionides [Tabula synoptica familiae Curculionidum] // Isis von Oken. T. 10. P. 1132-1146.

Schoenherr C. J. 1826. Cucrulionidum disposito methodica cum generum characteribus atque observationibus variis seu Prodromus ad Synonymiae Insectorum, part. IV. Lipsiae. Freischer. X+338 pp.

Voss E. 1937. Über Atren ostenasiatische Curculionoden (Coleoptera, Curculionidae) // Senkenbergiana, T. 19. No 3-4. P. 226-282. 


\section{References}

Alonso-Zarazaga M.A., Lyal Ch.H.C.A. 1999. World catalogue of families and genera of Curculionoidea (Insecta: Coleoptera) (Excepting Scolytidae and Platypodidae). Madrid: Entomopraxis. 315 p.

Arnoldi L.V. 1956. New weevils (Coleoptera, Curculionidae) from the Middle Asia. Entomologicheskoe obozrenie. 35(3): 680-692 (in Russain).

Arzanov Yu.G. 2003. Use of the Endophallus Characters in the Systematic of the Rhynchophorous beetles (Coleoptera, Curculionidae) Entomological Review. 83(8): 930-944.

Arzanov Yu.G. 2004. Review of Palaearctic weevils of the tribe Cleonini (Coleoptera: Curculionidae, Lixinae), inhabiting the Asteraceae. In: Trudy gosudarstvennogo prirodnogo zapovednika "Rostovskiy" [Proceedings of the State Nature Reserve "Rostovskiy"]. Vol. 3. Rostov-on-Don: 209-226 (in Russain).

Bedel L. 1909. Catalogue des Cleoniens (Coleoptera, Curculionidae) de l'Ėgypte et du Haut-Nil. Bulletin de la Société Entomologique d'Egypte. 2: $89-107$

Chevrolat L.A.A. 1873. Mémoire sur les Cléonides. Mémoire de la Société Royale des Sciences de Liége. 5(6): 1-118.

Dejean P.F.M.A. 1821. Catalogus de la collection de Coléoptères de M. le Baron Dejean. 8. Paris: Crevot. 136 p.

Dieckmann L. 1983. Beitrage zur Insektenfauna der DDR: Coleoptera Curculionidae (Tanymecinae, Leptopiinae, Cleoninae, Tanyrhynchinae, Cossoninae, Raymondionyminae, Bagoinae, Tanysphyrinae). Beiträge zur Entomologie. 33(2): 257-381.

Faust J. 1904. Revision der Gruppe Cléonides vrais. Deutsche Entomologische Zeitschrift. 1: 177-284.

Gistel J. 1856. Die Mysterien der europäischen Insectenwelt. T. 12. Kempten: Dannheimer. $532 \mathrm{p}$
Hustache A. 1929. Curculionidae. In: Voyage de Ch. Alluaud et R. Jeannel en Afrique Orientale (1911-1912). Rèsultats scentifiques, Coleoptera. T. 30. Paris: A. Schulz: 365-562.

Motschulsky V. 1860. Coléoptéres rapportés en 1859 par M. Sévertsef des Steppes méridionales des Kirghises, et enumerés par V. de Motschulsky. Bulletin Physico-Mathématique de l'Academie Impériale des Sciences de St. Petersburg. 2(8): 513-544.

Reitter E. 1912. Bestimmungs-Schlüssel der mir bekamnten europäschen Gattungen der Curculionidae, mit Einschluss der mir bekannten Gattungen aus dem palaearctischen Gebiete. Verhandlungen des naturforschenden Vereines in Brünn. 51: 1-90.

Reitter E. 1916. Fauna Germanica. Die Käfer des Deutsches Reiches. Band 5. Stuttgart: K.G. Lutz Verlag. 343 p.

Rye E.C. 1875. Insecta. Coleoptera. The Zoological Record. 10: 248-342.

Schoenherr C. J. 1823. Curculionides [Tabula synoptica familiae Curculionidum]. Isis von Oken. 10: 1132-1146.

Schoenherr C. J. 1826. Cucrulionidum disposito methodica cum generum characteribus atque observationibus variis seu Prodromus ad Synonymiae Insectorum, part. IV. Lipsiae: Apud Fridericum Fleischer. $\mathrm{X}+338 \mathrm{p}$.

Ter-Minassian M.E. 1988. Zhuki-dolgonosiki podsemeystva Cleoninae fauny SSSR. Kornevye dolgonosiki (Triba Cleonini) [Weevils of the subfamily Cleoninae of the USSR fauna. Tribe Cleonini]. Leningrad: Nauka. 233 p. (in Russian).

Voss E. 1937. Über Atren ostenasiatische Curculionoden (Coleoptera, Curculionidae). Senkenbergiana. 19(3-4): 226-282. 